\title{
Mechanisms for the intraseasonal variability of tropospheric ozone over the Indian Ocean during the winter monsoon
}

\author{
R. B. Chatfield, ${ }^{1}$ H. Guan, ${ }^{1,2}$ A. M. Thompson, ${ }^{3}$ and H. G. J. Smit ${ }^{4}$ \\ Received 29 March 2006; revised 21 December 2006; accepted 29 January 2007; published 17 May 2007.
}

[1] We synthesize daily sonde (vertical) information and daily satellite (horizontal) information to provide an empirical description of ozone origins over the northern Indian Ocean during the INDOEX (Indian Ocean Experiment) field campaign (February-March 1999). This area is shown to be a significant portion of the "high-ozone tropics". East-west $\mathrm{O}_{3}$ features and their flow are identified, and ozone origins are compared to other tropical regions, using water vapor as a second tracer. In the study period, multiple processes contribute to $\mathrm{O}_{3}$ column enhancements, their importance varying strongly by latitude: (1) Low-altitude $\mathrm{O}_{3}$ pollution over the northern Indian Ocean mainly originates from the Indian subcontinent and is traceable to high emission areas. Convective activity south of Sri Lanka helps direct ozone outflow from the northern Indian subcontinent. (2) Middle tropospheric $\mathrm{O}_{3}$ maxima over the northern Indian Ocean originate from various sources, often transitioning within a few hours. Convective venting of Asian pollutants can add $20-30 \mathrm{ppbv}$ to the middle troposphere at $5^{\circ} \mathrm{N}-10^{\circ} \mathrm{N}$, alternating with stratospheric influence. (3) A number of cases suggest that strong mixing-in of stratospheric air along the subtropical jet raised tropospheric $\mathrm{O}_{3}$ in early March by $\sim 40-50$ ppbv, especially poleward of $\sim 10^{\circ} \mathrm{N}$. (4) Influences of lightning and large-scale biomass burning were not strong during this period, in contrast to the situation in Africa and the South Atlantic or locally in Southeast Asia. This work illustrates successes and limitations in approaches to synthesizing disparate information on trace-gas distributions taken from satellite retrieval products and ozonesondes.

Citation: Chatfield, R. B., H. Guan, A. M. Thompson, and H. G. J. Smit (2007), Mechanisms for the intraseasonal variability of tropospheric ozone over the Indian Ocean during the winter monsoon, J. Geophys. Res. 112, D10303, doi:10.1029/2006JD007347.

\section{Introduction}

[2] Since satellite techniques have been applied to estimate tropospheric ozone, they have reinforced the idea that longitudinal variations in tropospheric ozone are at least as important as latitudinal variations in the tropics. Behavior of tropical tropospheric $\mathrm{O}_{3}$ is very different from the stratosphere or the extratropical troposphere. Routhier et al. [1980] and Piotrowicz et al. [1986] described "very low tropospheric ozone," even to less than $1 \mathrm{ppb}$, in the equatorial Pacific, based on shipboard and aircraft measurements, and Logan and Kirchhoff [1986] described an especially high-ozone region of the tropics. Fishman et al. [1990] made a more vivid picture with satellite measurements of ozone, describing an Atlantic high-ozone region ( 35-50 Dobson units of ozone column-integrated density, DU) and a west-central Pacific low-ozone region $(\sim 15-$

\footnotetext{
${ }^{1}$ Earth Science Division, NASA Ames Research Center, Moffett Field, California, USA.

${ }^{2}$ Bay Area Environmental Research Institute, Sonoma, California, USA.

${ }^{3}$ Department of Meteorology, Pennsylvania State University, University Park, Pennsylvania, USA.

${ }^{4}$ Forschungszentrum Jülich, Jülich, Germany.

Copyright 2007 by the American Geophysical Union. 0148-0227/07/2006JD007347
}

$20 \mathrm{DU})$ which persisted, with variations, year-around. The high- and low-ozone regions were better delineated in a zonal view of the ozone cross section and integrated column, provided through the tropical Southern Hemisphere additional ozonesondes (SHADOZ) network [Thompson et al., 2003]. Edwards et al. [2003] pooled information from satellites on $\mathrm{CO}$, ozone, and lightning to assess origins of the maximum. In a recent study by Wang et al. [2006], the high- and low-ozone contrasts within the tropics were clearly delineated by Stratospheric Aerosols and Gases Experiment (SAGE), an instrument that added profile information to the total and tropospheric column views of the Total Ozone Mapping Spectrometer (TOMS) instrument.

[3] The Indian Ocean area initially received little attention, appearing to have moderate or even low concentrations of ozone [Logan, 1999; Liu et al., 2005], although lowaltitude pollution was evident [Krishnamurti et al., 1998] and large-scale studies seemed warranted. Chatfield et al. [2004] recently spotlighted the region as a contributing source for the Atlantic ozone maximum, using satellite and sonde information. Analyses using a variety of new techniques and satellites reported by Fishman et al. [2003], Kim et al. [2001, 2005], and Liu et al. [2005] reveal the Indian Ocean region to be transitional in magnitude $(\sim 25-$ 30 DU) but still part of "high-ozone tropics," that include the Indian Ocean, Africa, the Atlantic Ocean, and South 
America. The Southeast Asian region and easternmost and westernmost equatorial Pacific have intermediate values [Oltmans et al., 2001], varying by week, season, and year. The high-ozone tropics thus constitutes $50 \%-60 \%$ of the entire equatorial belt, $20^{\circ} \mathrm{S}$ to $20^{\circ} \mathrm{N}$. The semiempirical dynamical analysis applied by Hudson and Thompson [1998] placed the Indian Ocean region in the intermediateto-high-ozone tropics.

[4] The Indian Ocean Experiment (INDOEX), carried out from 23 February to 30 March 1999 [Lelieveld et al., 2001], provides invaluable observations about the chemical composition of the Indian Ocean atmosphere during the winter monsoon season (between December and March), a period of maximum surface pollutant accumulation from both South and Southeast Asia [Phadnis et al., 2002]. The "brown cloud" associated with these emissions has stimulated considerable investigation because of its large impact on the solar radiative heating and regional gas phase chemistry of the region [Lal et al., 1998]. Summarizing this, Lelieveld et al. [2001] showed that during the winter monsoon, South and Southeast Asian emissions cause considerable air quality degradation over an area in excess of 10 million $\mathrm{km}^{2}$. The lowermost-tropospheric $\mathrm{O}_{3}$ peaks result from pollutants originating out of South Asia and Southeast Asia, which are carried to the Indian Ocean during the Northern Hemisphere winter by monsoon winds from the northeast [Lal et al., 1998; Peshin et al., 2001; Phadnis et al., 2002].

[5] However, when we began to examine tropical ozone over Africa and the Atlantic Ocean, a variability manifested itself over the Indian Ocean that seemed more complex than a straightforward pollution picture. Other work stimulated by the INDOEX field investigations also led to various suggestions regarding the sources and transport mechanisms of ozone over the Indian Ocean, especially high- $\mathrm{O}_{3}$ peaks. For example, upper-tropospheric laminar $\mathrm{O}_{3}$ maxima have been attributed to Stratospheric-Tropospheric Exchange (STE) [Zachariasse et al., 2000, 2001]. Similar attributions have been made in the southern Indian Ocean [Baray et al., 1998]. Using trajectory analysis and INDOEX measurements, Zachariasse et al. [2000, 2001] showed that STE along the subtropical jet (STJ) was prominent for uppertropospheric $\mathrm{O}_{3}$ in 1999. Model simulations [de Laat, 2002] indicated that a major source of the midtropospheric $\mathrm{O}_{3}$ maxima is advection of polluted air masses from continental biomass burning areas over Africa, with generally only a small contribution of stratospheric $\mathrm{O}_{3}$. These results would appear to be at variance except that the authors concentrated analysis on different regions of the troposphere.

[6] It is well known that Intertropical Convergence Zone (ITCZ) clouds can loft pollutants into the upper atmosphere, where they can spread over large areas. Our recent analysis [Chatfield et al., 2004] showed that convective lofting can move Indian Ocean pollutants into the upper troposphere where some paths transport them to the southern Atlantic Ocean, partly explaining the "tropical Atlantic paradox" [Thompson et al., 2000]. Moxim and Levy [2000] described the role of lighting in the same area, using model simulations. Phadnis et al. [2002] estimated that convective lifting of transported pollution $\mathrm{O}_{3}$ from South and Southeast Asia supplies about $10 \%$ of the $\mathrm{O}_{3}$ in the tropical upper troposphere during January, February, and March 1999.
[7] Integrative studies using INDOEX-period satellite observations to explore ozone intraseasonal variability in the INDOEX and adjacent regions have not been performed. In this paper, we take advantage of Total Tropospheric Ozone (TTO) maps, derived from the Earth Probe TOMS measurements. We find these data useful, although the satellite reports total column tropospheric ozone, which makes it difficult to attribute a height to source processes, especially when several sources act simultaneously at differing levels.

[8] Series of individual TTO maps display east-west streaks or bands of high ozone, a term adopted for recurrent and elongated regions of high ozone that extend E-W or ENE-WSW between the South China coast and the Atlantic Coast of Brazil (see Figures 2 and 3 of Chatfield et al. [2004]). The bands are not always continuous in space or time, but appear to result from large-scale nearly zonal winds, tropospheric flow pattern near the equator that acts on high ozone from a variety of origins. The important point is that this streaking is usually distinct from more rounded ozone buildups associated with subtropical high-pressure centers, the latter being the prominent areas previously described with satellite and in situ measurements [Martin et al., 2002; Fishman et al., 2003].

[9] The current work defines and explains the ozone maxima commonly associated with banding over the Indian Ocean. The satellite maps define the overall geographic variability, but we begin with ozonesonde profiles from the Kaashidhoo Observatory on Male $\left(5^{\circ} \mathrm{N}, 73^{\circ} \mathrm{E}\right)$ and a shipboard platform to delineate the altitude structure of specific features. Additional information from the profiles, for example, water vapor concentrations from the sondes, allows more confident source attributions. In turn, the TOMS satellite ozone maps define the geographic scale of significant processes. Focusing on lower and middle tropospheric $\mathrm{O}_{3}$, we attempt to place convective redistribution [Chatfield and Delany, 1990; Chatfield et al., 2004] within the context of various ozone buildups observed by the satellite over the Indian Ocean. Other processes are found to be important, for example, stratospheric ozone, but lightning appears not to be, at least for this study period.

\section{Sondes and Satellite Data}

[10] The INDOEX ozonesondes and radiosondes were launched from the National Oceanic and Atmospheric Administration (NOAA) Research Vessel Ronald H. Brown, $(\mathrm{r} / \mathrm{v} R H B)$ along the tracks shown in Figures 1 and 4 (discussed later) during the period 23 February to 30 March 1999. Sondes were launched at least two times a day and more often when the ship approached the Arabian Sea, where pollution influences were expected. We also used the special sonde data set from daily launches during this period at Kaashidhoo, $5^{\circ} \mathrm{N}, 73^{\circ} \mathrm{E}$ (Figure 2 [Thompson et al., 2003]). The Kaashidhoo sondes fill in the two time periods (gray in Figure 1) when the ship was in port. The shipboard and island records appear similar but differ in an important way. While Figure 1 essentially samples time variability from 1 day to the next, the ship also samples geographic variability, most importantly further away from the equator, at $\sim 12^{\circ} \mathrm{N}-18^{\circ} \mathrm{N}$. Figure 2 for the Kaashidhoo station shows time variability at one near-equatorial position. 
a.
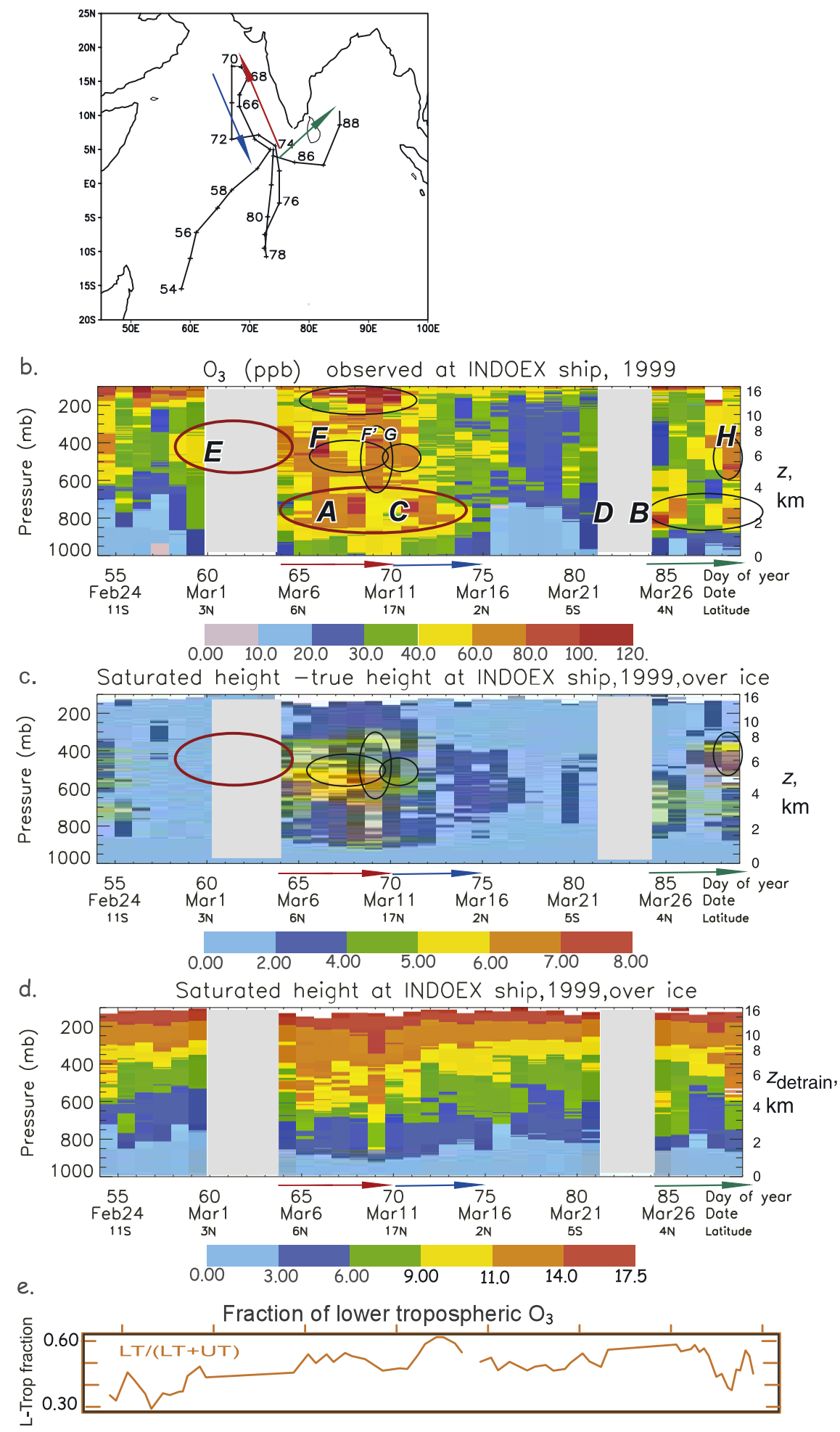

Figure 1. (a) Ship tracks of the 1999 INDOEX Ron Brown cruises, with segments north from Kaashidhoo marked. (b) Ozone mixing ratio (ppbv), and (c, d) two quantities summarizing water vapor content from the 1999 Ron Brown INDOEX cruise launched between $15^{\circ} \mathrm{S}$ and $17^{\circ} \mathrm{N}(24$ February to 30 March 1999). Figure 1c indicates the change in altitude due to such subsidence. Mixing of air parcels or evaporation of ice falling into a subsiding parcel complicates this analysis. Figure 1d indicates the height in the atmosphere at which a parcel would detrain if its water vapor mixing ratio were completely conserved from the point of last detrainment from a cloud (where it was saturated with respect to ice). (e) Fraction of tropospheric ozone that is in the lower troposphere (below $500 \mathrm{hPa}$ ): TOMS is less sensitive to lower tropospheric ozone. 

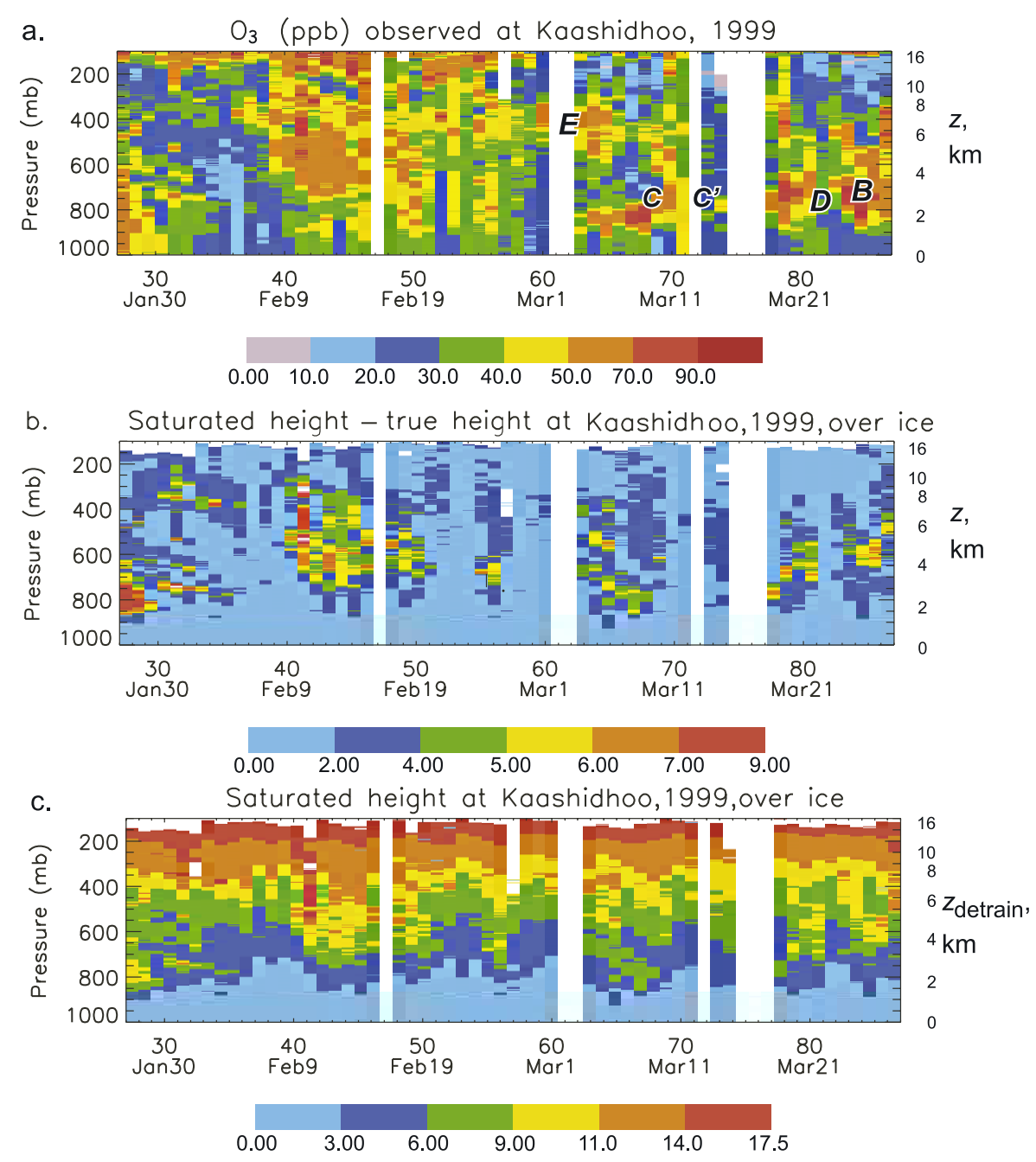

Figure 2. Kaashidhoo ozone mixing ratio and water vapor presented in similar form to Figure 1. (a) Ozone mixing ratio (ppb); (b) subsidence distance calculated from water vapor mixing ratio; (c) altitude of detrainment calculated similarly.

[11] Ozone profile measurements were made with balloonborne electrochemical concentration cell (ECC) ozonesondes coupled with a standard radiosonde and a sensor for relative humidity [Komhyr, 1986; Komhyr et al., 1995]. The accuracy of the ozone sensor varies from $\pm 1-2$ ppbv below $5 \mathrm{~km}$ to $\pm 5 \mathrm{ppbv}$ at $10 \mathrm{~km}$ and $\pm 20 \mathrm{ppbv}$ at 20 -km altitude [Smit et al., 1994; H. G. J. Smit et al., Assessment of the performance of ECC-ozonesondes under quasi-flight conditions in the environmental simulation chamber: Insights from the Jülich Ozone Sonde Intercomparison Experiment (JOSIE), submitted to Journal of Geophysical Research, 2007, hereinafter referred to as H. G. J. Smit et al., submitted manuscript, 2007]. RS80-technology sensors gave the sondes good relative humidity response in the upper troposphere. A detailed description of the INDOEX soundings is given in the work of Peshin et al. [2001]. Following Thompson et al. [2003], tropospheric $\mathrm{O}_{3}$ column is determined by integration to a "chemical tropopause" which is defined as the point at which the $\mathrm{O}_{3}$ mixing ratio, followed downward from the stratosphere, reaches $100 \mathrm{ppbv} \mathrm{O}_{3}$.

[12] Satellite total tropospheric $\mathrm{O}_{3}$ column (TTO) data at a $2^{\circ} \times 1^{\circ}$ grid are based on the modified residual (MR) method [Thompson and Hudson, 1999]. We take care with
TTO because backscatter ultraviolet instruments best detect $\mathrm{O}_{3}$ between $\sim 550 \mathrm{hPa}$ and the tropopause [Hudson et al., 1995; Martin et al., 2002; Kim et al., 2005]. The modified residual provides estimates for nearly everyday that there is a TOMS overpass (approximately two of every 3 days for the 1999 INDOEX period because situations with excessive cloudiness are omitted for accuracy). The method depends on a partially subjective evaluation of a sinusoidal "wavenumber-one" variation of the stratospheric/tropospheric partition of background ozone with longitude for each latitude band. No estimates are made in latitudes approaching the Himalayas, where smaller-scale processes may make the assumption of a single sinusoid inadequate. Tapered 5-day running averages were used to smooth TTO and fill-in gaps. Tapered averaging involves weighting the average so that initial and final terms of the sum contribute less than the central terms; large changes are most noticeable at a time in the filtered series closest to their position in the original time series [Jenkins and Watts, 1968], while the benefits of averaging are preserved.

[13] In evaluating the TTO satellite ozone product [Thompson and Hudson, 1999] for use in this study, we compared 5-day tapered-average TOMS tropospheric $\mathrm{O}_{3}$ 


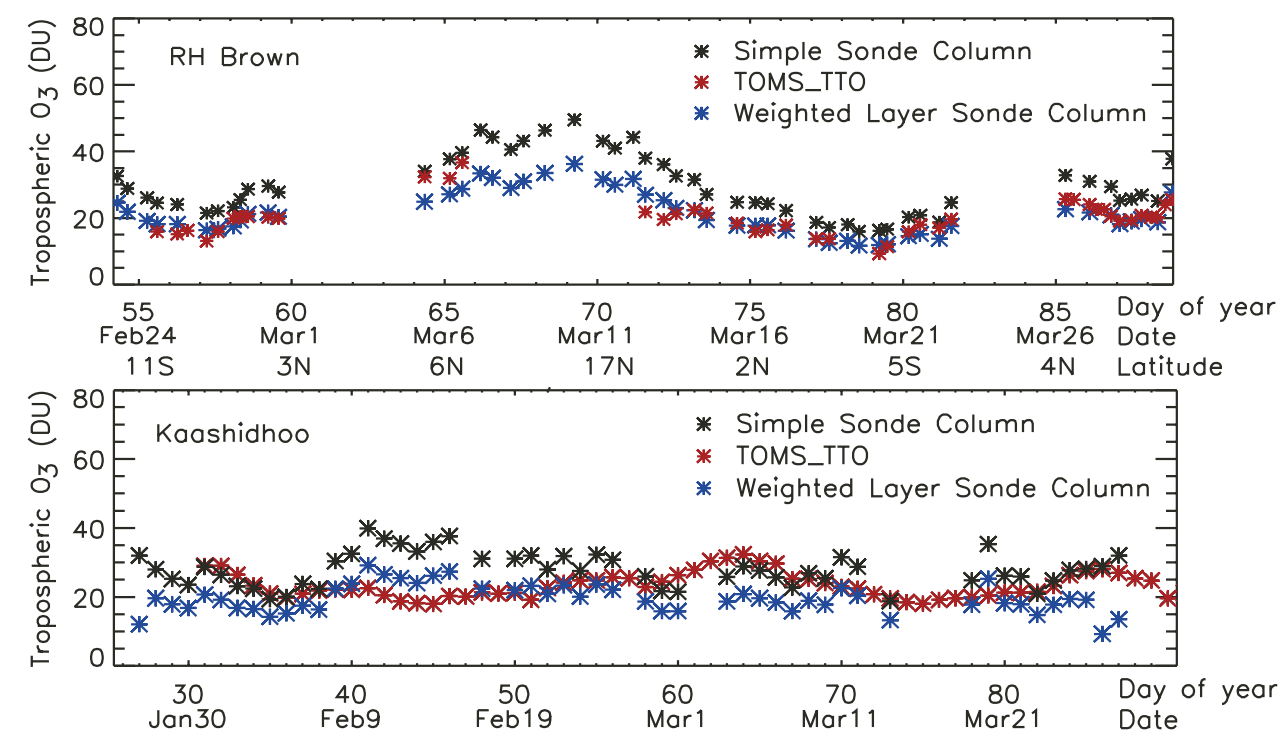

Figure 3. (a) Tropospheric $\mathrm{O}_{3}$ column amount from sondes compared to TOMS TTO (red) along the r/v RHB cruise tracks during the 1999 INDOEX period. Two column ozone amounts are indicated: Black symbols indicate a simple sum of the sounding, while blue symbols are a sum emphasizing upper tropospheric contributions. (b) Similar comparisons using a separate data set, the Kaashidhoo sonde set. Comparisons are generally good: Exceptional periods are discussed in text.

with sonde $\mathrm{O}_{3}$ along the ship track. Comparisons are kept to the region between $10^{\circ} \mathrm{S}$ and $10^{\circ} \mathrm{N}$, as summarized in Figure 3. A large variation of tropospheric $\mathrm{O}_{3}$ with latitude is observed during INDOEX, with a minimum of $16 \mathrm{DU}$ at $10^{\circ} \mathrm{S}$ and a maximum of $50 \mathrm{DU}$ at about $20^{\circ} \mathrm{N}$. Both curves show a tendency for tropospheric $\mathrm{O}_{3}$ to increase with increasing latitude. In general, TOMS TTO follows the integrated sonde $\mathrm{O}_{3}$, but with a systematic underestimation, partly because TOMS has diminished sensitivity to lower tropospheric ozone [Hudson et al., 1995; Martin et al., 2002, and references therein]. The mean difference between the sonde and satellite tropospheric $\mathrm{O}_{3}$ is about $6 \mathrm{DU}$, comparable to the precision of the modified residual technique [Thompson and Hudson, 1999]. We made a simple least squares regression fit of the TOMS TTO values against the partial-column amounts of ozone below $500 \mathrm{hPa}$ and from the 500-hPa level to the tropopause. The results are in Figure 3 and show an improved correspondence to the TTO trace. The regression suggested a slight diminution of response to ozone at atmospheric regions below $500 \mathrm{hPa}$,

$$
\mathrm{TTO}=0.83 I_{500} \cdots \text { Trop }+0.62 I_{\mathrm{Sfc}} \cdots 500
$$

where $I_{500} \cdots$ Trop indicates the integrated tropospheric ozone (in Dobson units) from $500 \mathrm{hPa}$ to the chemical tropopause, and $I_{\mathrm{Sfc}} \cdots 500$ indicates the integrated tropospheric ozone from the surface to $500 \mathrm{hPa}$. Figure 1e shows that the fraction of (sonde-derived) ozone in the lower troposphere (surface, $500 \mathrm{hPa}$ ) varies considerably, from $\sim 30 \%$ to $60 \%$. Figure $3 \mathrm{a}$ indicates that the correlation is good considering that the TTO product must be averaged (inherently lowering correlation), with correlation coefficient for the regression 0.81. The relationship does not do so well with Kaashidhoo ozonesonde record. Figure $3 \mathrm{~b}$ also shows the results when we used the same formula for that ozonesonde set, and also a simple sum. Several short-term variations are well reproduced using the formula, but the correlation is near zero and not significant. It appears that a single period of 9 days starting in around 6 February lowered the correlation, with low TTO but high sonde data. For much of the period, there seems to be a nearly constant $\sim 15$ DU offset of low TTO (or high sonde ozone). Other days had less variation and so could not contribute much to produce a good correlation. One hypothesis is that the TTO method failed during this period because of small-scale variations of the TTO ozone distribution or an inadequate understanding of the process by which stratospheric ozone becomes tropospheric ozone. For example, high values identified by sondes as ozone in the uppermost troposphere may have originated in the stratosphere but have been transformed by vertical mixing to a tropospheric temperature structure, while retaining trajectories similar to stratospheric overlying air. This explanation would describe a reasonable limitation to the TTO technique: inability to follow occasional small-scale tropical-subtropical mixing processes. Nevertheless, the ship measurements, with their greater variation and geographical sampling, may be considered a reasonable general validation, given the precision of TTO and the sondes ( $\sim 5 \%$ in the troposphere [H. G. J. Smit et al., submitted manuscript, 2007]), and increases our confidence in the use of TTO over the Indian Ocean region for the INDOEX period.

[14] Supporting measurements. Visible Infrared Radiation Sensor (VIRS) estimates, a monthly averaged product based on thermal emission of radiation from fires ("hot pixels"), indicates open-field or open-forest burning [Giglio et al., 2000]. National Centers for Environmental Prediction (NCEP) daily outgoing longwave radiation (OLR) data with a resolution of $2.5^{\circ} \times 2.5^{\circ}$ were applied to identify regions of convective clouds. The NASA/Goddard kinematic trajectory model (detailed description in the study by Schoeberl and Newman [1995]) was used to calculate air parcel trajectories. 

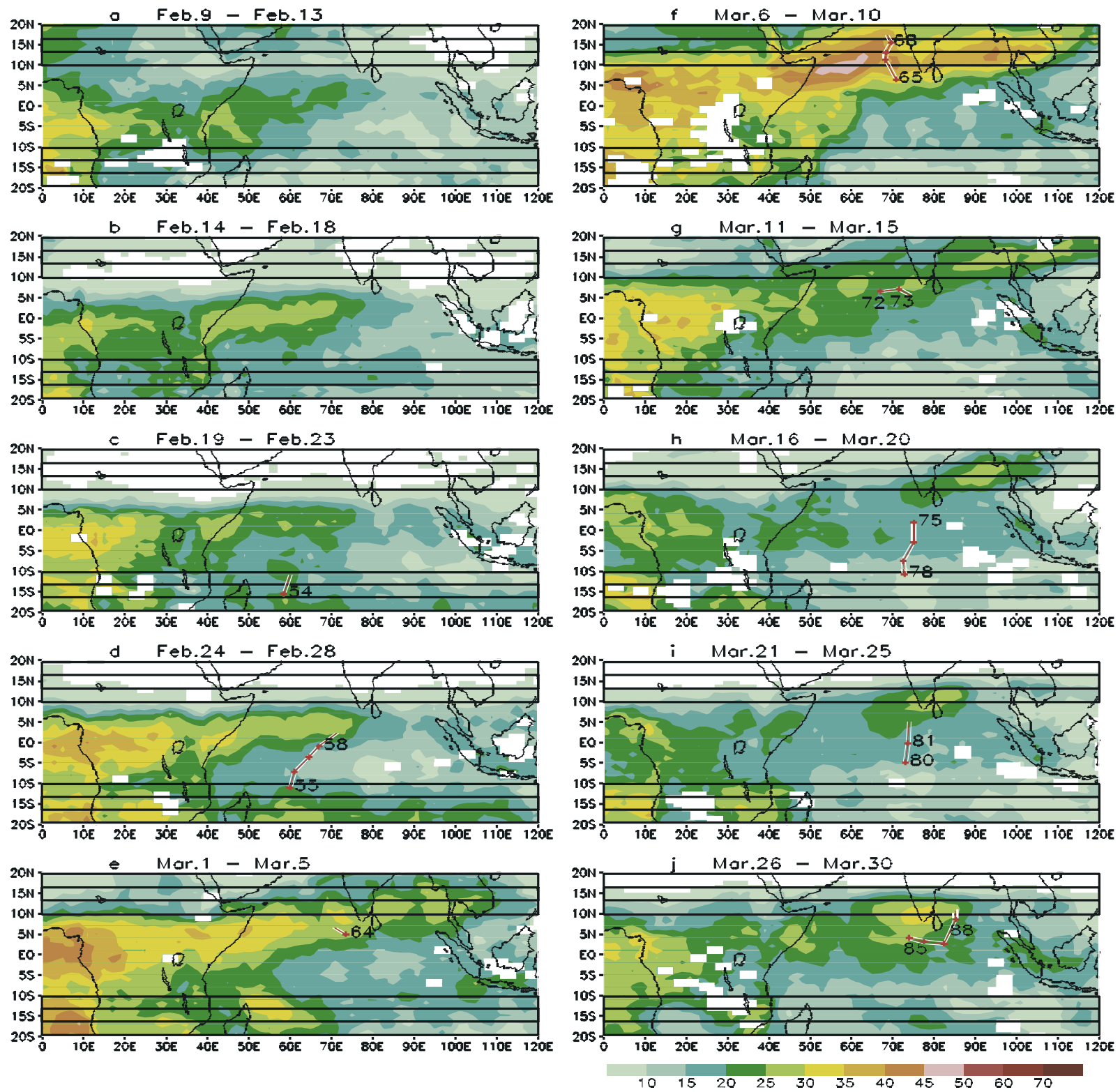

Figure 4. Five-day averaged TTO (DU) during the 1999 INDOEX. The horizontal bars drawn beyond $10^{\circ}$ latitude are a reminder that the retrieval method is considered most reliable only within $10^{\circ} \mathrm{S}$ and $10^{\circ} \mathrm{N}$ because of the assumptions that are made about the zonal invariance of $\mathrm{O}_{3}$ in the tropical stratosphere and susceptibility to transitory extratropical influences affecting stratospheric $\mathrm{O}_{3}$ column.

The model uses analyzed NCEP 6-hour three-dimensional wind fields at a resolution of $2.5^{\circ} \times 2.5^{\circ}$.

[15] Note that trajectories are not expected to trace back accurately to individual cloud updrafts. However, in the work of Chatfield and Crutzen [1984], we showed that significant portions of the upper troposphere could have high concentrations of short-lived ( $1-3$ days) species because of the vigor of the narrow updrafts. Convectively active regions of the tropics $(\sim 500$ to $\sim 1000 \mathrm{~km}$ wide in our example) should be influenced by cloud updrafts: $\sim 1$-day refresh (or "flow-through") timescales for the lowest $1.5 \mathrm{~km}$, and $\sim 2$-day refresh times for upper tropospheric outflow regions. Convective systems tend to form, persist, and decay over periods of several days. In more recent studies, Pickering et al. [1992, 2001] presented situations where tracing trajectories back to convective cloud activity (evidenced by OLR) successfully highlighted lower tropospheric influence. Assimilations of Advanced Very High Resolution Radiometer (AVHRR) data by Rasch et al. [2001] are used to interpret aerosol optical depth in terms of a sum of several components. The assimilation procedure apportions daily AVHRR optical depth among species responsible for extinction. We use one product, hydrophilic black-carbon containing aerosol, one which signifies sulfate- or nitrate-covered aerosol pyrogenic aerosol. This parameter should be representative of smog aerosols in the region, well correlated with lower tropospheric ozone [Lal et al., 1998], and a signal of the effects of industrial, urban, and rural combustion of various fuels. This indicator is a simulation product in contrast to the 

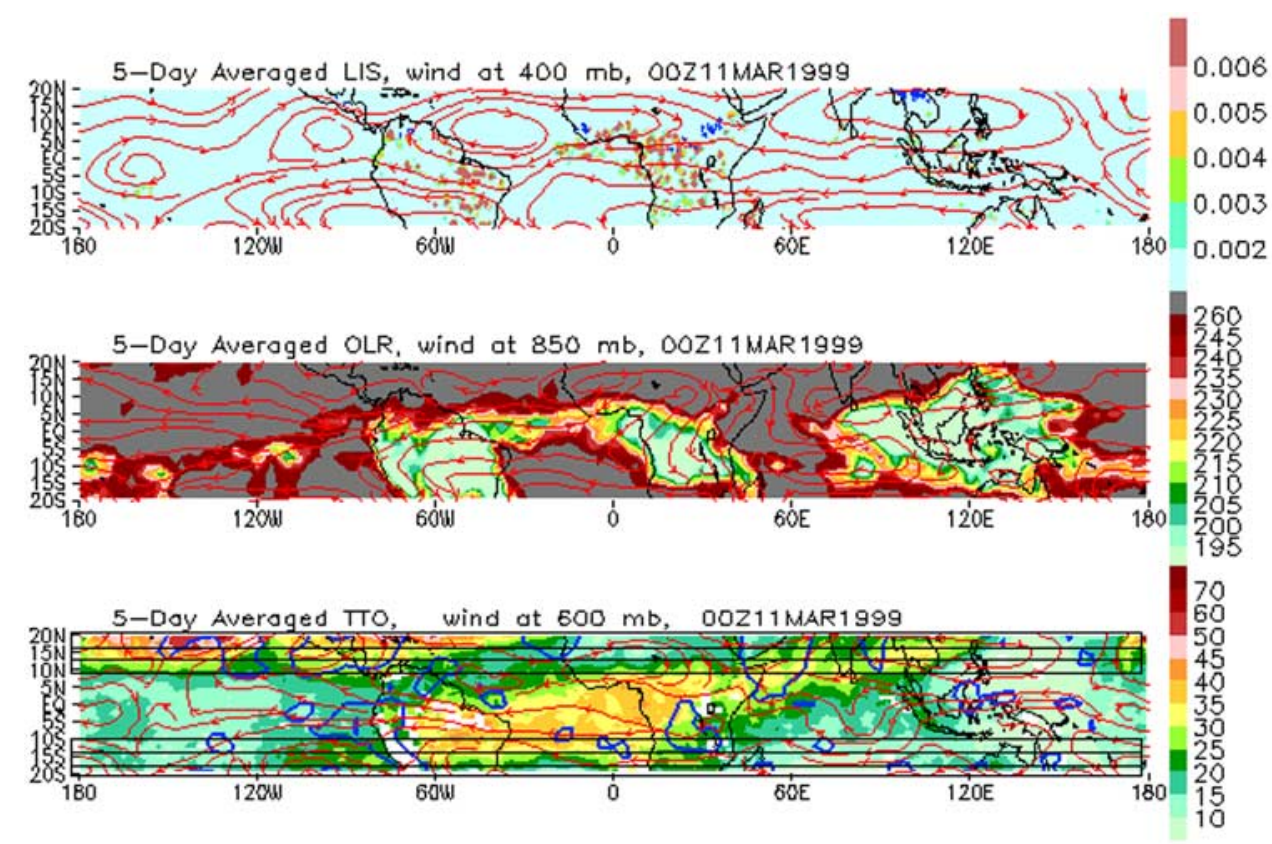

Figure 5. Three-panel map of ozone, lightning, and cloud occurrence with streamlines (movie sample). Top panel: Lightning strike rate $\left(\mathrm{s}^{-1}\right)$ and monthly biomass burning incidence [see Chatfield et al., 2004], 400-hPa wind streamlines, good for estimating upper-tropospheric transport. Middle panel: Daily cloud incidence from Outgoing Longwave Radiation, $850-\mathrm{mb}$ winds indicating inflow to convective systems. Bottom panel: TTO estimates (filtered by tapered running mean) in Dobson units, 600-hPa middletropospheric wind streamlines.

other data employed, but the assimilation ties it to the INDOEX-period observations. Meteosat water vapor and cloud products are also used in the analysis.

\section{TTO: General Features}

[16] Consecutive maps of the 5-day averaged TTO product are displayed in Figure 4 for the INDOEX period, covering the latitudes between $20^{\circ} \mathrm{S}$ and $20^{\circ} \mathrm{N}$. Positions of the $\mathrm{r} / \mathrm{v} R H B$ are shown as a red track with dates.

[17] A more useful overview of both general and detailed features is available in a movie that depicts TTO, lightning, burning, and convection for February and March 1999 over the entire tropical region (available in Supplementary Material). The animation enhances individual images presented here and lends support to the interpretations. Figure 5 gives an example frame. Markings for TTO follow the description given above. The top panel indicates lightning flash rate, based on TRMM Lightning Imaging Sensor (LIS; 5-day averages) and from VIRS fire incidence [Chatfield et al., 2004; Giglio et al., 2000]. The middle panel gives a diel-average picture of cloud activity via OLR that indicates the prevalence of cloud top surfaces with varying cloud top temperatures (altitudes). The bottom panel indicates TTO. All three frames provide information on winds. Lower level streamlines at $850 \mathrm{hPa}$ are indicated in the middle panel to indicate inflow to tropical convective systems. Middle level winds are implicated for longer distance transport; 400-hPa winds appear in the top panel with LIS lightning. The TTO product is plotted with $600-\mathrm{hPa}$ winds that tend to be coherent up to $200 \mathrm{hPa}$. Winds at no single level appear to correlate perfectly with kinematic TTO patterns, but winds integrating transport between 600 and $200 \mathrm{hPa}$ correlate most often.

[18] Three striking features of these maps are (1) their large temporal and spatial variability, (2) a "theme with variations" of spatially mottled regions of high ozone in the vast region between the Andes eastward to Indonesia/ Indochina/Australia (see also Chatfield et al. [2004] and references therein), and (3) the lack of strong lighting and biomass burning influences. Lightning and ozone for INDOEX do not reflect the strong linkages indicated by trajectories over the Atlantic. Studies by Dickerson [1984], Edwards et al. [2003], Jenkins et al. [2003], and Chatfield et al. [2004] all show lightning as a prime contributor to nitrogen oxides and subsequently to $\mathrm{O}_{3}$, especially at the end of the biomass burning season and the onset of tropical rains [Thompson et al., 1996].

[19] The maps may suggest that lightning is occasionally correlated with high TTO further eastward, over the larger islands and land areas of Southeast Asia, but the effects do not reach our focus area, the central Indian Ocean area. Lightning, biomass burning, and transport from Africa possibly play a role in other seasons and years, but our examination of the January-March 1998 record for the INDOEX sounding region suggests similar results to those in early 1999.

\section{Detailed Origins of Tropospheric $\mathrm{O}_{3}$ Maxima}

[20] The ozone soundings provide a more detailed study of tropospheric ozone maxima suggested by the TTO. We begin with an example of pollutant lofting which affected Africa and the Atlantic, and then proceed to study in 


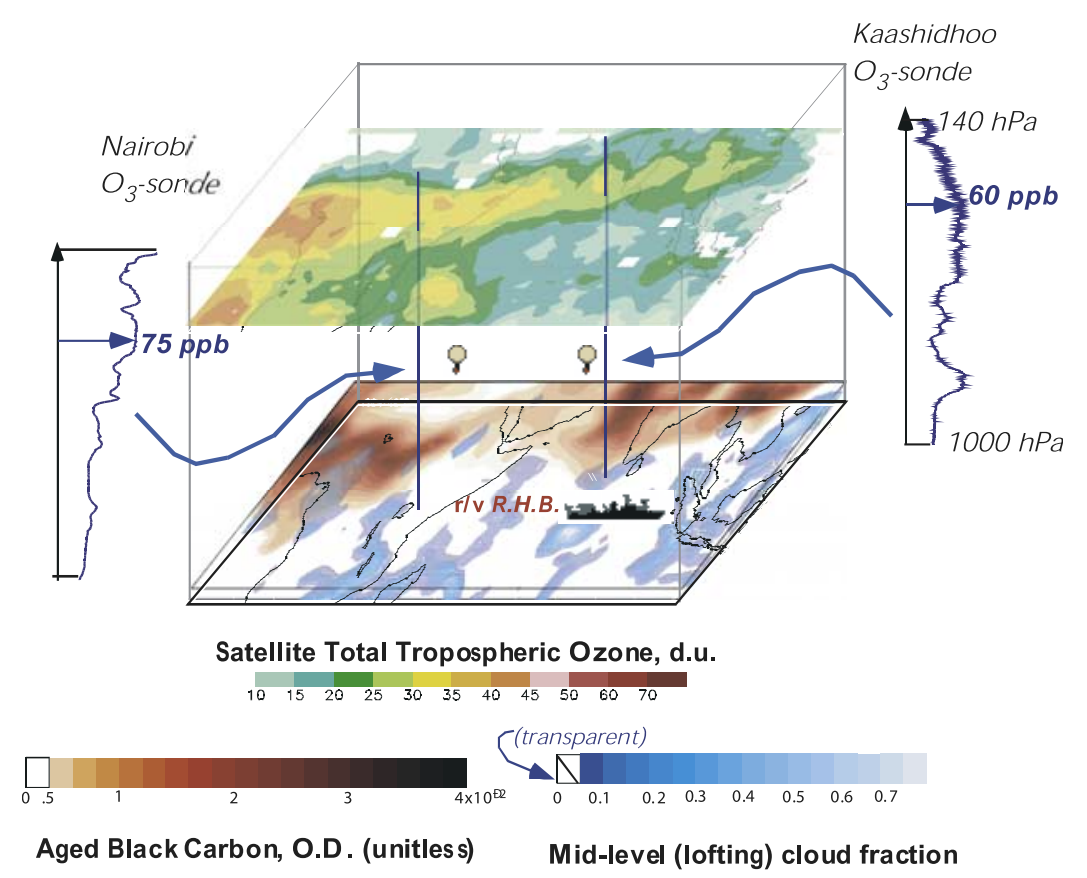

Figure 6. Conceptual model of smog export from South Asia and lofting of smog ozone to the middle and upper troposphere, based on interpretation of empirical satellite observations of the Indian Ocean area. Red tones reflect assimilated hydrophilic or aged black-carbon associated aerosol optical depth, blue colors indicate midlevel clouds, and top-colored map indicates TTO, total tropospheric ozone. Two sondes also indicate ozone at the two stations marked, indicating the detailed structure that comprises tropospheric ozone column amount. See text for details.

temporal sequence maxima in the lower and then upper troposphere during the period when the TTO is augmented by information of the sondes. This provides information on the frequency of different influences and their modes.

\subsection{Pollutant Lofting of Ozone, an Illustrative Example}

[21] Figure 6 illustrates the venting of smog ozone; for further clarification, see the Supplementary Material movie. Variations and details of this mechanism and descriptions of a few situations in which it seems not to operate constitute the rest of our analysis. Figure 6 is a conceptual picture of ozone export and subsequent lofting from polluted South Asian regions as elucidated by satellite observations and soundings [Edwards et al., 2003]. The situation occurred on 5 March, as the $\mathrm{r} / \mathrm{v} R H B$ left port. The brown tones at the bottom of the figure represent a "brown cloud" aerosol mix, i.e., contours of hydrophilic (aged) black carbon aerosol optical depth as assimilated by Rasch et al. [2001]. This smog-aerosol material is advected out at low levels from South Asia toward clouds, i.e., a convective convergence region.

[22] The graphic in Figure 6 shows the middle of a period of high TTO, on a day when the time-averaged TTO intensifies markedly. (Recall that weighting the means toward the central day allows us to capture processes as close to the actual event as possible.) Reference to the movie gives the impression of a weak band of high TTO appearing on 27 and 28 February toward the east, near a small convective cloud disturbance, shown by the OLR. A disturbance near the southern tip of India is visible on
5 March. Low-level streamlines suggest a short transport path from the polluted subcontinent. Studies using trajectories are described in a following section.

[23] Lower tropospheric $\mathrm{O}_{3}$ over the Indian Ocean is mainly controlled by monsoon flow. In winter (dry monsoon), the Indian Ocean monsoon winds generally blow from the northeast but vary somewhat from week to week. Consequently, pollution from South Asia and Southeast Asia can be carried out over the northern Indian Ocean [Phadnis et al., 2002; Lelieveld et al., 2001].

[24] A second step, convective lofting in the Arabian Sea to the west of India is indicated by midlevel clouds reported by the assimilation model, predominantly clouds that extend from the aerosol layer to the upper troposphere and are presumed to carry out the venting. In the figure, these are blue tones overlaid just above the brown. Third, the multicolored area in the upper troposphere represents TTO (weighted to the upper troposphere) that displays a streak traveling the west-southwest toward Africa. Finally, r/v $R H B$ ozone profiles near Kaashidhoo and in Nairobi, Kenya, show the complexity of vertical structure of tropospheric ozone. The sonde in the Indian Ocean shows an intense pollution layer in the lower troposphere and a lofted region of ozone reaching $60 \mathrm{ppbv}$. The Nairobi sonde, to the east, shows high-altitude tropospheric ozone, with a maximum reaching 75 ppbv.

\subsection{Patterns in the Soundings Time Series}

[25] The time series of low-level $\mathrm{O}_{3}$ (Figure 1) from the INDOEX $\mathrm{r} / \mathrm{v} R H B$ sondes varies widely, from $10 \mathrm{ppbv}$ over the pristine southern Indian Ocean to $80 \mathrm{ppbv}$ over the 
polluted Arabian Sea and northern Indian Ocean. The lower tropospheric $\mathrm{O}_{3}$ maxima are, in general, located at 700$850 \mathrm{hPa}$. Observations at Kaashidhoo (Figure 2) show similar variability, but the lower tropospheric maxima at
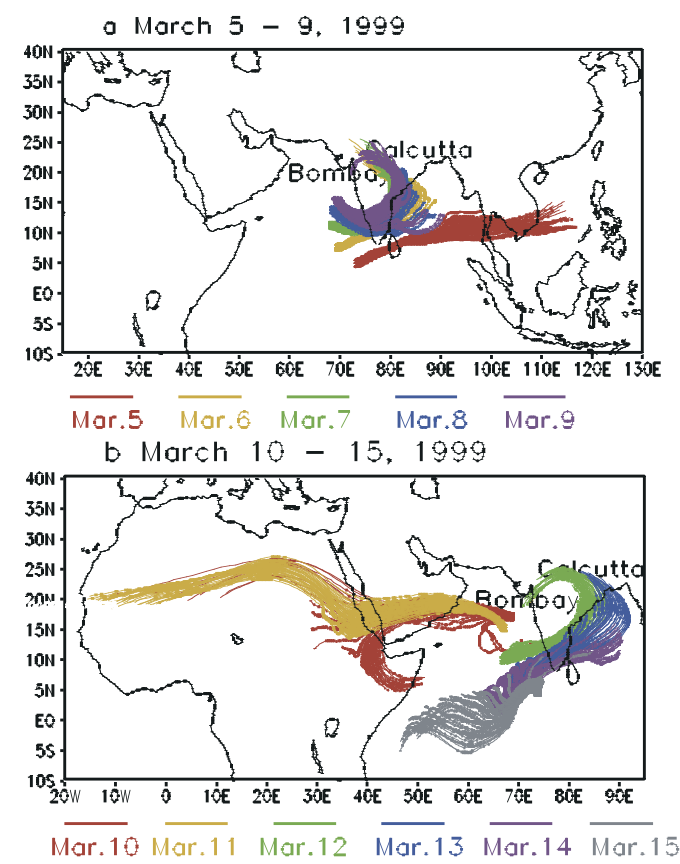

c Morch 8, 1999

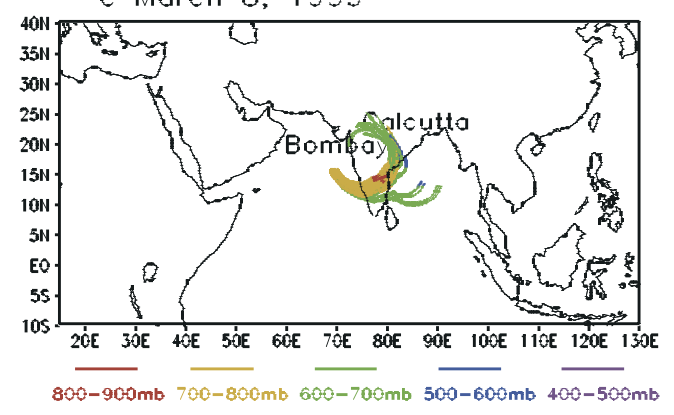

d March 13, 1999

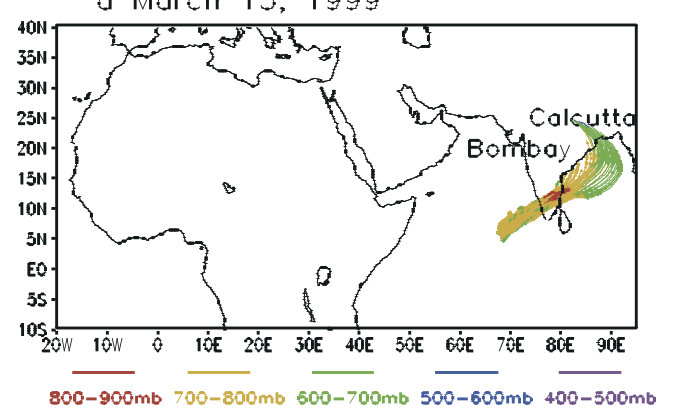

e Population Density (persons/ $\mathrm{km} 2$ )

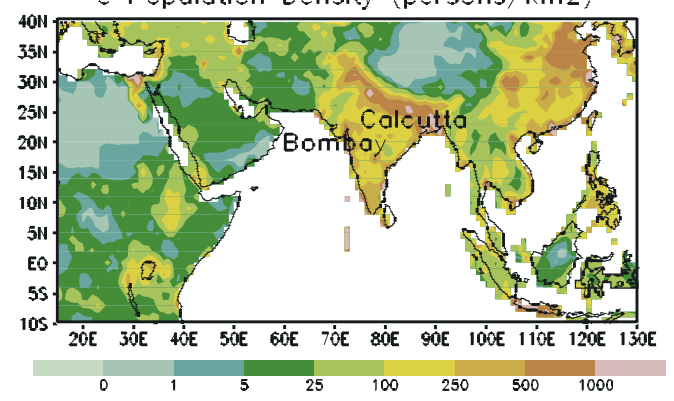

times extend as high as $500 \mathrm{hPa}$, as is discussed below. Similarly, weak maxima are also seen in those $\mathrm{r} / \mathrm{v} R H B$ soundings made near Kaashidhoo or a few degrees south of the equator. A separate region of ozone maxima is frequently seen aloft, ranging from $\sim 500$ to $\sim 250 \mathrm{hPa}$.

[26] The rest of this section examines ozone maxima at each level in more detail. When these analyses over the 1999 period are viewed as a whole and interpreted with supplementary data, they imply the frequency and locations of different influences.

\subsection{Origins of Lower Tropospheric $\mathrm{O}_{3}$ Over the Indian Ocean}

[27] The first component of the multistep smog-ozone flow outlined above is low-level pollutant outflow. Figure 7 displays a cluster of 6-day back trajectories from the $\mathrm{r} / \mathrm{v}$ $R H B$ at several levels $(710,730,750,770$, and $790 \mathrm{hPa})$ each day, 5-15 March, a time when high $\mathrm{O}_{3}$ mixing ratios at low altitudes were observed (see Figure 1a). These elevated $\mathrm{O}_{3}$ concentrations coincided with higher values and air parcel trajectories passing over the northern Indian subcontinent, especially the highly populated and industrialized northern arc and the Ganges Plain. The figure shows population density: Lower population densities in India are associated with land that is unable to support either a population or industry. Household burning emissions also tend to follow population density. Corroborative evidence of pollution comes from AVHRR total aerosol optical depth (AOD) during the INDOEX time period [Rasch et al., 2001; Lal et al., 1998]. Two local maxima (AOD exceeding 0.4) in the areas near Calcutta and Bombay suggest very strong emission of carbonaceous compounds and sulfate precursors (region marked A of ozone soundings in Figure 1). That temporal maximum of lower tropospheric $\mathrm{O}_{3}$ in 7-9, 12, and 13 March appears to originate from the two (megacity) emission regions. This is consistent with observations that the southeastern part of the Arabian Sea is repeatedly strongly influenced by an aerosol and ozone pall originating from the Indian subcontinent [Rasch et al., 2001]. Relatively low $\mathrm{O}_{3}$ values tend to correlate with clean oceanic air or air from lower-emission continental regions. Previous studies have indicated that not all polluted areas produce ozone [Raman et al., 2002; Reiner et al., 2001]. The lower portions of Figure 7 depict specific days, 8 and 13 March, where the color coding signifying vertical motion of the trajectories is generally subsident, consistent with patterns described by Raman et al. [2002].

Figure 7. Six-day 750-hPa back trajectories along the 1999 INDOEX cruise track between 5 and 15 March, illustrating lower-tropospheric transport of pollution towards the equatorial Indian Ocean. Top figures use color coding to track clusters of trajectories from points near the launch location; bottom figures show vertical motion (often decent) associated with the two characteristic days, 8 and 13 March. Trajectories passing through populated and industrialized areas of the Indian subcontinent are associated with greater lower-tropospheric $\mathrm{O}_{3}$ in Figure 1, but days with other air mass origins, e.g., 10, 11, and 16 March, have low to moderate ozone. 


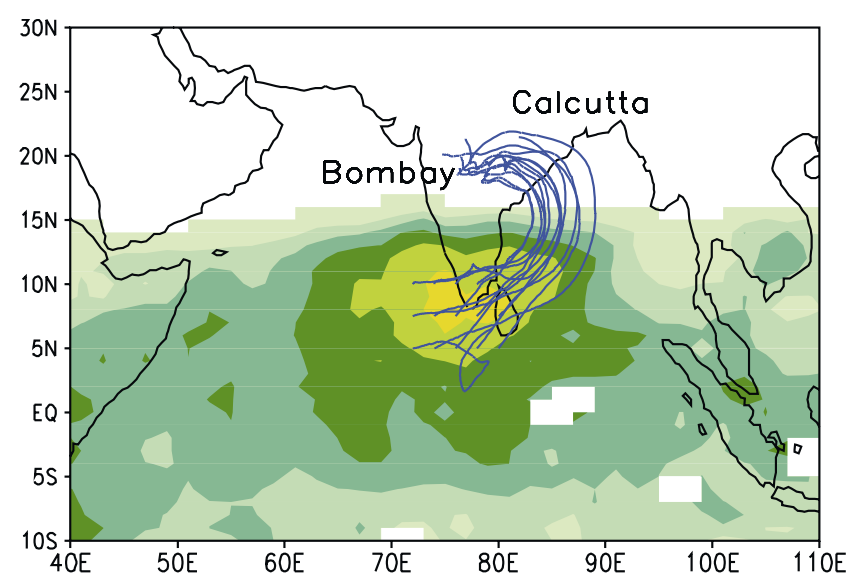

Figure 8. Five-day averaged TTO (DU) and cluster of 800 $\mathrm{hPa}$ streamlines for 26 March 1999. Six-day back trajectories from Kaashidhoo are shown for every $20 \mathrm{hPa}$ between 850 and $800 \mathrm{hPa}$ suggesting results of $\mathrm{O}_{3}$ transport from polluted areas of India. Color scale: see Figure 4. $\left(\mathrm{O}_{3}\right.$ is not easily estimable north of $15^{\circ} \mathrm{N}$ for this day.)

[28] The time-averaged TTO shown in Figure 4 also suggests an ozone maximum over the region of the ship tracks (days 65-68 and 73), suggesting that a large area of the Arabian Sea is affected. Since the soundings for the period show high-ozone layers throughout the troposphere, it is not easy to say how the TTO pattern reflects lower tropospheric ozone. (Figure 1e shows the fraction of lower tropospheric ozone for the ship sonde series.)

[29] In a second period of analysis, the results of transport of pollution from high emission regions to the region $5^{\circ} \mathrm{N}-$ $15^{\circ} \mathrm{N}$ in the Indian Ocean also appear in the TTO map for 26 March (Figure 8). A localized ozone buildup is seen in the figure. Note the high TTO column near South India and surrounding coast that is dominated by low-level $\mathrm{O}_{3}$, as identified by the vertical distribution of ozone in $26 \mathrm{March}$ (Figure 1, marked B). That profile was taken as the r/v RHB had finished its Arabian Sea transect and was near Kaashidhoo $\left(4^{\circ} \mathrm{N}, 73^{\circ} \mathrm{E}\right)$. The ship was at the edge of the TTO view, and this might be the reason that the region marked "B" in Figure 1 has only a modest lower-tropospheric buildup. The 6-day back trajectories (Figure 8) for 26 March at several levels $(800,820$, and $840 \mathrm{hPa})$ suggest that the high ozone may have arrived from high emission areas of northern India, although regions near Madras and Bangalore may also contribute [Forêt et al., 2005]. A similar trajectory analysis of the period 21-25 March compared to the Kaashidhoo record (the ship was mostly in port) is not shown. The analysis suggests influence from the mostly oceanic Isthmus of Kra region which progresses rapidly back toward influences from polluted northeast India; lower tropospheric ozone that arose seen in the Kaashidhoo sondes is roughly coincident; this analysis conforms our picture.

[30] This analysis of the lower tropospheric ozone (Figures 1 and 4) emphasizes that pollution outflow tends to occur above the marine boundary layer, predominantly between $900 \mathrm{hPa}(1 \mathrm{~km})$ and $600 \mathrm{hPa}(4 \mathrm{~km})$, as explained for INDOEX in the works of Reiner et al. [2001], Raman et al. [2002], and Forêt et al. [2005]. The lowest kilometer probably does not participate as pollutant outflow from a warm daytime continental mixed layer flows up and over a cooler marine layer. At night, continental mixed layer heights and winds in the lower polluted layers would be restrained and exported easily.

\subsection{Organization by Convection of Pollutant Flow}

[31] The variation of lower tropospheric $\mathrm{O}_{3}$ over the northern Indian Ocean is affected by convective activity in the ITCZ directly to the south. Increased convection near the equator is associated with lower-tropospheric inflow and the southward movement of pollution. Consider the region marked " $\mathrm{C}$ " in Figure 1 and " $C$ " and " $C$ " " in Figure 2, up to $3 \mathrm{~km}(700 \mathrm{hPa})$. Further describing this episode, Figure 9 compares the OLRcloud and daily TTO for 10 and 14 March. On 10 March, the west boundary of ITCZ precipitation was near $73^{\circ} \mathrm{E}$, whereas on 14 March, the corresponding boundary had retreated eastward to $83^{\circ} \mathrm{E}$. TTO near Kaashidhoo on 10 March is about 5-10 DU higher than on 14 March. Strong convection on 10 March, just south of Sri Lanka, is associated with an increased meridional wind between the highly polluted Calcutta area and the active ITCZ region. Streamlines suggest that on 10 March, the general airflow moving south from the polluted Calcutta region was stronger than later, on 14 March.

[32] To generalize the strength of this effect, we compared wind strengths within an appropriate rectangle: $15^{\circ} \mathrm{N}-20^{\circ} \mathrm{N}$ and $80^{\circ} \mathrm{E}-90^{\circ} \mathrm{E}$. The averaged southward wind on $10 \mathrm{March}$, about $1 \mathrm{~m} \mathrm{~s}^{-1}$ larger than on $14 \mathrm{March}$, suggests more vigorous influence. On 10 March, the polluted air masses from Calcutta flowed to the convective region as indicated by low-level back trajectories originating from Kaashidhoo. Thus $\mathrm{O}_{3}$ or $\mathrm{O}_{3}$ precursors over India can be carried out into Kaashidhoo. However, on 14 March, pollutant air masses from the Calcutta area were diverted by weakening southward winds. The weakening wind is consistent with the retreating convection, a well-known phenomenon of tropical meteorology [Krishnamurti et al., 1975]. As a consequence, on 14 March and later, lower tropospheric $\mathrm{O}_{3}$ at Kaashidhoo originated from cleaner ocean regions.

[33] How frequent is the oscillation between more and less polluted influences? The sondes launched from Kaashidhoo provide information to address this. Figure 10 shows the time series of integrated lower tropospheric $\mathrm{O}_{3}$ (between 600 and $900 \mathrm{hPa}$ ) at Kaashidhoo $\left(5^{\circ} \mathrm{N}\right.$ and $\left.74^{\circ} \mathrm{E}\right)$ and OLR just south of Sri Lanka $\left(5^{\circ} \mathrm{N}\right.$ and $\left.80^{\circ} \mathrm{E}\right)$. The latter spot was selected as generally "upwind" during southwardflow intervals. This time series confirms the example comparing 10 and 14 March. Two minimum OLR (high cloudiness) values on 6 and 25 March reveal strong convective precipitation south of Sri Lanka. On the other hand, low-level $\mathrm{O}_{3}$ in Kaashidhoo displays the maximum in 9 March, 3 days later than the first minimum OLR. This illustrates a period of equatorial convection and coordinated low-level flow from the South Asia to the Indian Ocean. Figure 10 also shows an anomaly for the low-level $\mathrm{O}_{3}$ for the period 22-25 March, although strong convection prevailed. This low-ozone region is marked " $D$ " in Figures 1 and 2. However, inspection of the OLR figures (not shown) for 22-25 March indicates that a region of convective precipitation had just moved 
OLR and Wind at 850mb, OOZ10MAR1999

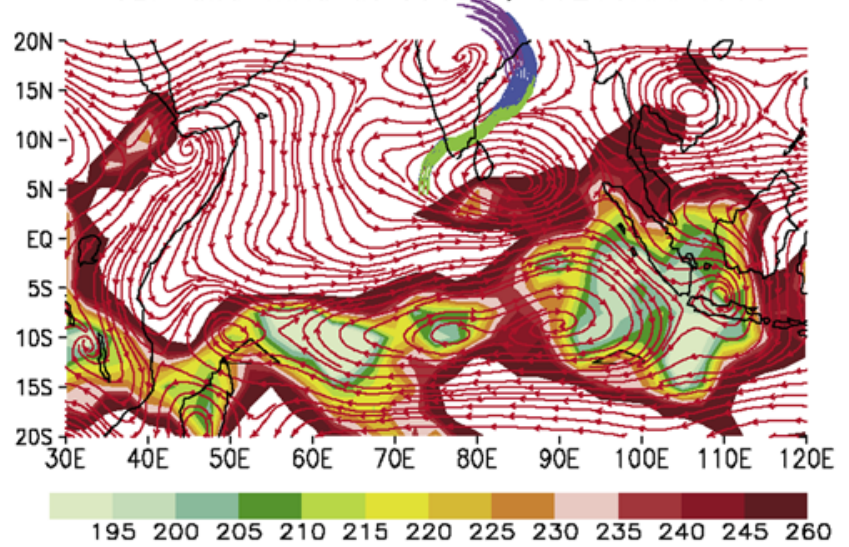

TTO, OOZ1OMAR 1999

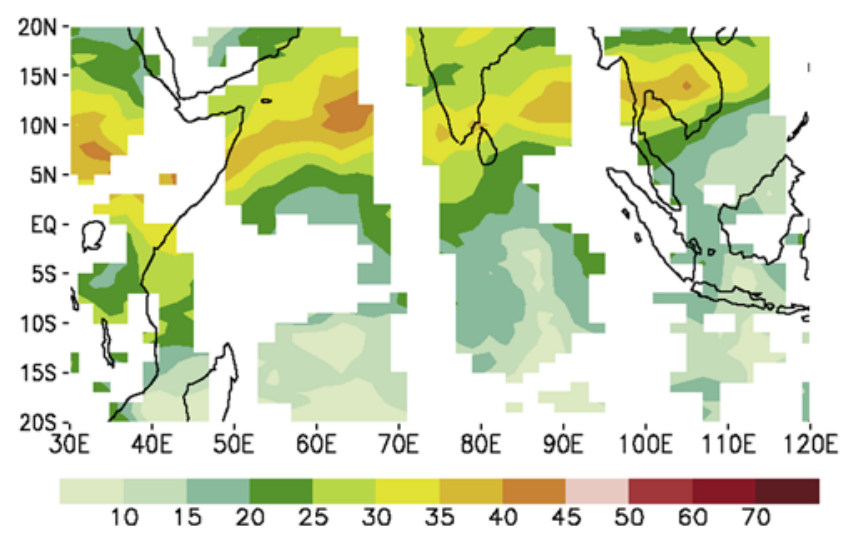

OLR and Wind at $850 \mathrm{mb}$, OOZ14MAR1999

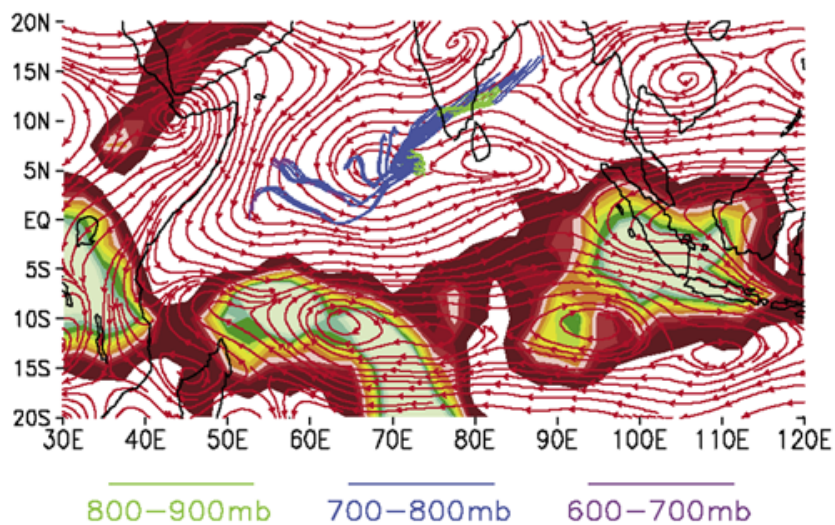

TTO, OOZ14MAR1999

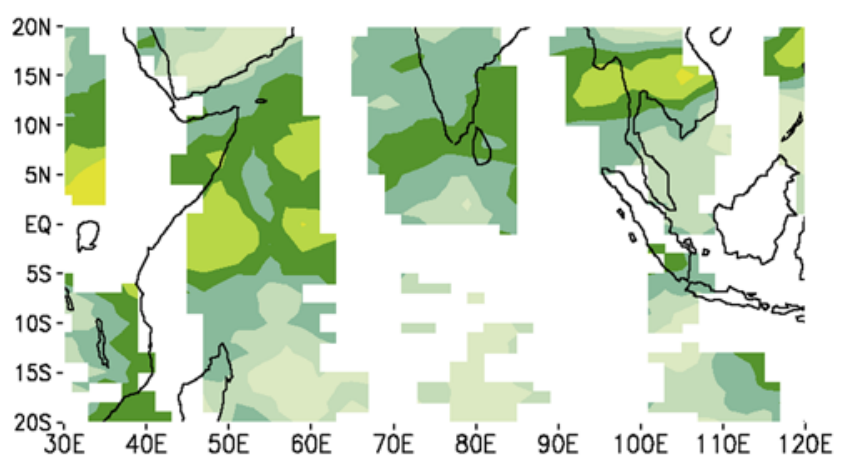

Figure 9. Outgoing longwave radiation and 850-hPa streamlines for (a) 10 March 1999 and (b) 14 March 1999. Six-day back trajectories from Kaashidhoo are shown for every $100 \mathrm{hPa}$ between 900 and $600 \mathrm{hPa}$. Five-day averaged TTO (DU) for (c) 10 March 1999 and (d) 14 March 1999. Trajectories are color-coded to indicate vertical motion using a scheme similar to Figures $7 \mathrm{c}$ and $7 \mathrm{~d}$.

upwind of Kaashidhoo, suggesting that perhaps the lowlevel tropospheric $\mathrm{O}_{3}$ had already been lofted to the upper troposphere. This alteration of cloudiness and flow has been analyzed as a local manifestation of the Madden-Julian Oscillation [Rasch et al., 2001] during INDOEX.

\section{Competing Influences on Middle Tropospheric $\mathrm{O}_{3}$}

[34] Now consider ozone in regions above 3-4 km deriving from this lofting mechanism as compared to other sources. The mechanisms affecting middle and upper tropospheric $\mathrm{O}_{3}$ over the Indian Ocean are more complicated and varied. The most significant mechanisms suggested in previous work are as follows:

[35] (1) South Asian and Southeast Asian large-scale biomass burning.

[36] (2) South Asian varied combustion.

[37] (3) Pollutants lofted to the middle troposphere by ITCZ cloud after they transported to the Indian Ocean [Phadnis et al., 2002; Chatfield et al., 2004]. Exchanges of pollutant influences may reach back and forth from the Mediterranean and Europe [Lawrence et al., 2003; Vingarzan, 2004].

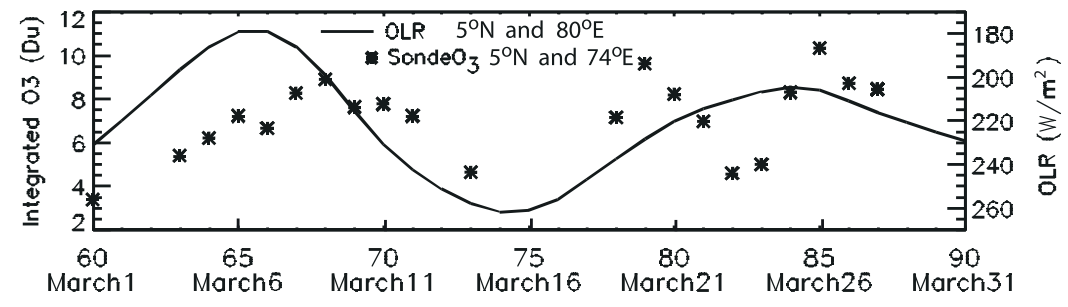

Figure 10. Time series of OLR $\left(\mathrm{W} \mathrm{m}^{-2}\right)$ south of Sri Lanka $\left(5^{\circ} \mathrm{N}, 80^{\circ} \mathrm{E}\right)$ and integrated (surface, $500 \mathrm{hPa})_{3}$ sondes (DU) in Kaashidhoo in March 1999. 


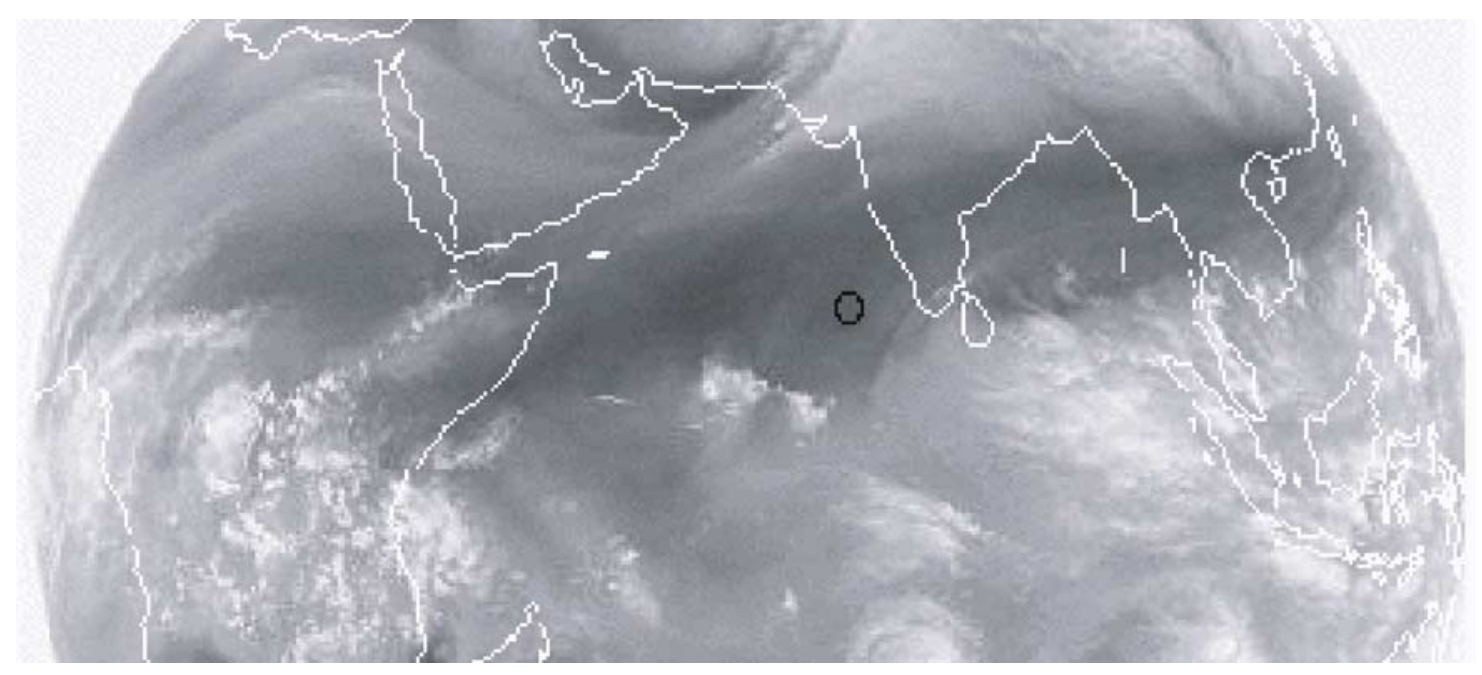

Figure 11. Meteosat 5 water vapor image for 6 March 1999 indicating a very dry region in the Arabian Sea where high ozone was indicated by soundings and TTO.

[38] (4) Stratospheric $\mathrm{O}_{3}$ transported toward the midtroposphere and deep tropics by STE in the upper troposphere near the STJ [Zachariasse et al., 2001].

[39] (5) African biomass burning which is lofted by convective cloud and then transported to the Indian Ocean along STJ.

[40] (6) Lightning may play a role in certain seasons.

[41] Analyses using TTO, trajectories, and cloud top (OLR) data [Chatfield et al., 2004] showed how a rapid increase of TTO at the end of February (Figure 4b) over the Indian Ocean appeared a result from convective lofting of transported South/Southeast Asian pollutants. This ozone eventually crossed equatorial Africa to contribute to regional Atlantic ozone, a mechanism partly described by Krishnamurti et al. [1996].

[42] Ozone buildups from the sources just described might be carried westward in a similar way, as shown by local maxima labeled " $E$ " through " $G$ " in Figure 1. The sonde $\mathrm{O}_{3}$ and relative humidity (saturated height difference) profiles for 27 and 28 February (Figures 1 and 2, marked "E") observed from the $\mathrm{r} / \mathrm{v} R H B$ reinforce the impression of lofted pollution. The middle tropospheric $\mathrm{O}_{3}$ maximum values are between 40 and $60 \mathrm{ppbv}$, and relative humidity is also above $50 \%$ (suggested in the figure by regions in light blue) indicating convective lofting. Over the next several days, the $\mathrm{r} / \mathrm{v} R H B$ was in port, and the Kaashidhoo soundings for 1-6 March show similar influences: high ozone without indications of large descent (high saturatedheight differences). In general, convective lofting contributes about 20-30 ppbv to the middle tropospheric $\mathrm{O}_{3}$.

[43] There are contrasting examples suggesting other origins, probably stratospheric. At the beginning of March, the $\mathrm{O}_{3}$ band seen often during this part of the monsoon season shifted toward the north (Figures $4 \mathrm{e}$ and $4 \mathrm{f}$ ), and this leads to the highest TTO over the southern Arabian Sea, $55-70^{\circ} \mathrm{E}$, $5-10^{\circ} \mathrm{N}$. Peak TTO (more than $45 \mathrm{DU}$ ) occurred around March 6 (Figure 4f). The observations from the nearby $\mathrm{r} / \mathrm{v}$ RHB (Figure 1, marked " $\mathrm{A}$ ") confirm that the middle tropospheric $\mathrm{O}_{3}$ over the Arabian Sea is especially high between 6 and 12 March, 60 ppbv. Starting on 6 March, the corresponding relative humidity is very low, less than
$10 \%$ (regions of saturated height differences $>5 \mathrm{~km}$, yellow and red colors), indicating strong subsidence, possibly even a strong injection of dry stratospheric air.

[44] High-ozone, low water periods are examined in more detail. Figures $1 \mathrm{c}, 1 \mathrm{~d}, 2 \mathrm{~b}$, and $2 \mathrm{c}$ show the humidity structure of the troposphere, assuming water vapor to be a conserved tracer; that is, subsidence from a detraining cloud top explains changes in the relative humidity. Appendix A gives an approach for interpreting ozone-water vapor soundings. Under the general assumptions described therein, the origins of the driest regions associated with high ozone must be from the upper troposphere $(>\sim 11 \mathrm{~km}$, Figure 1d), or possibly a mixture of even drier stratospheric air with somewhat moister tropospheric air. This source attribution and several that follow cannot be distinguished from a distant burning/pollution source vented to the uppermost troposphere, or similarly very dry and less mixed with moist air [Mandal, 2002]. In no case, however, was there a convincing pattern of trajectories from tall clouds which could unambiguously point to such pollutant source regions.

[45] A satellite view of the midtropospheric dry region can be also seen in the Meteosat 5 water vapor image (Figure 11). The image indicates dry (dark coloration) and moist (bright) regions in the layer of the atmosphere about 6-10 $\mathrm{km}$ above the surface. On 6 March, the dry region extends over the entire southern Arabian Sea.

[46] Possible indications of stratospheric influence occur several times when the $\mathrm{r} / \mathrm{v} R H B$ was at its northernmost points, $12^{\circ} \mathrm{N}-17^{\circ} \mathrm{N}$. As Figure 1 indicates, most of the period 7 March (with one intense peak, "F") to 10 March (a more vertically distributed maximum, $\mathrm{F}^{\prime}$ ) and 30 March (marked " $\mathrm{H}$ ") share features with similar $\mathrm{O}_{3}$ maxima and relative humidity minima. This northern region is a common location of the streaks or bands seen in Figure 4, where TTO evidently detects dry, descending, ozone-rich features. These appear much diluted if they reach the deep equatorial tropics, for example, $12^{\circ} \mathrm{N}$ to $12^{\circ} \mathrm{S}$. The limited period of the sondes suggests that convective lofting is most significant for the deep equatorial tropics and most likely to move westward, across Africa. 

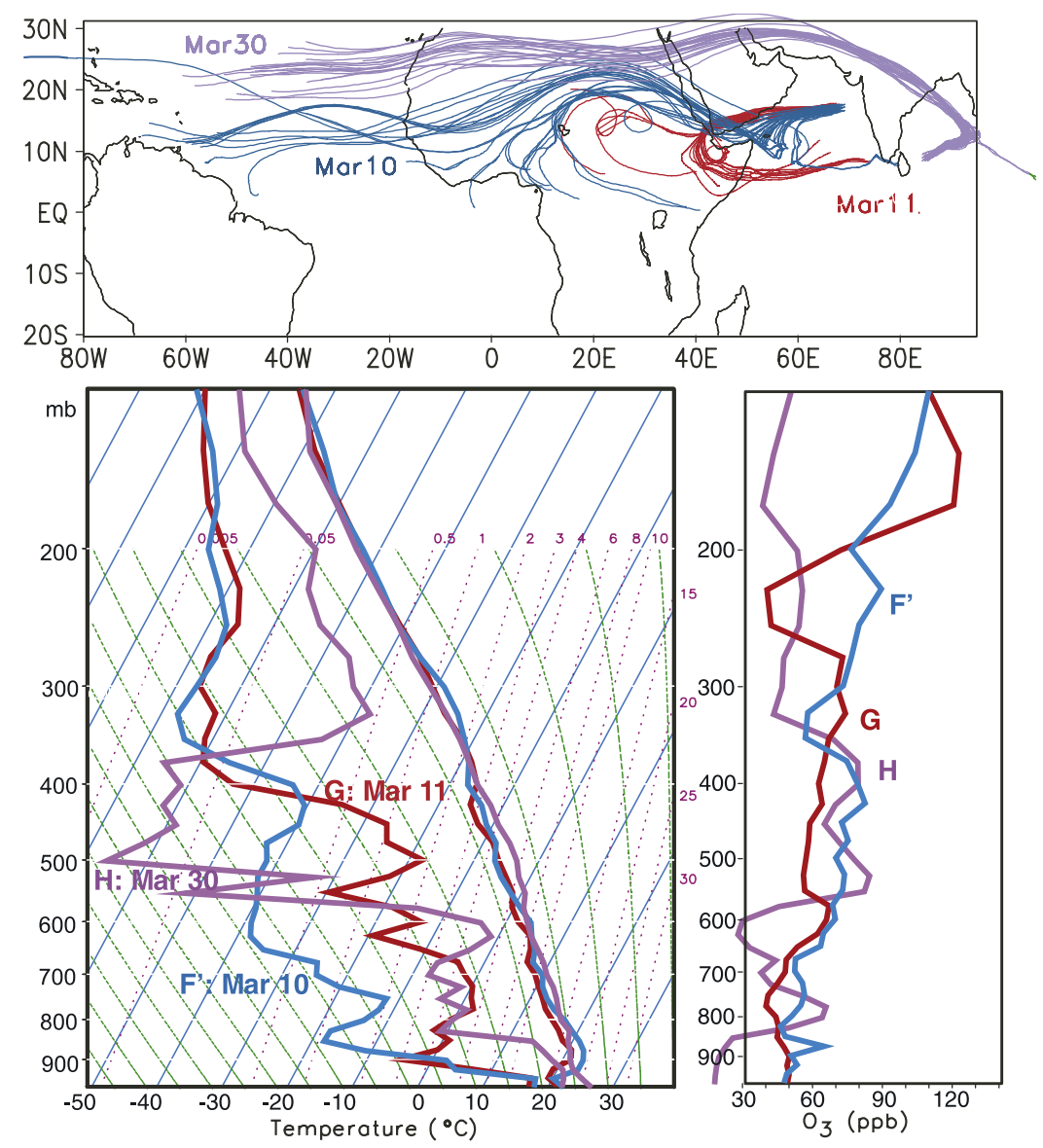

Figure 12. Skew-T diagrams of thermodynamic structures for days with midtropospheric ozone concentrations (profiles shown on right). All are in the northern range of the $\mathrm{r} / \mathrm{v} R H B$. One high ozone region is likely stratospherically influenced $(\mathrm{H}, 30 \mathrm{March})$, one possibly stratospherically influenced, $\left(\mathrm{F}^{\prime}, 10 \mathrm{March}\right)$, and one influenced by pollution lofting out of South Asia (G, 11 March). This is indicated by trajectories for the peak ozone regions of the three soundings, shown above.

[47] The Kaashidhoo soundings are examined in detail using the $\mathrm{F}^{\prime}$ and $\mathrm{G}$ events as portrayed in thermodynamic diagrams of Figure 12. The samples $\mathrm{F}^{\prime}$ and $\mathrm{G}$ (10 and $11 \mathrm{March}$ ) show similar $\mathrm{O}_{3}$ concentrations. The high-ozone sounding on 30 March (this one northward in the Bay of Bengal) is also similar. It was show in vertical detail on 30 March that high ozone at $\sim 450 \mathrm{hPa}$ is strongly associated with very dry air. $\mathrm{At}^{\prime}, \mathrm{O}_{3}$ maxima are also correlated with relatively dry air. However, the days marked " $G$ " have nearly as high $\mathrm{O}_{3}$, follow the " $\mathrm{F}^{\prime \prime}$ " region of strongly subsiding air, but are much moister. For the latter, convective lofting of pollution is a more likely process. Ozone, clouds, and winds shown in the animation of sequential images for the period suggest that convection has moved northward into the southern Bay of Bengal. Pollution aloft $(>50 \mathrm{ppb}$ at $\mathrm{G})$ is associated with partial ventilation of pollution below ( $>40 \mathrm{ppb}$ just before $\mathrm{C})$, although winds are from the east at both levels. Trajectories for $\mathrm{H}, 30$ March (Figure 12), have the recurving pattern of stratospheric influence noted by Zachariasse [2000]. For F', 10 March is somewhat similar but does not recurve anticyclonically. Indeed, trajectories for the whole period $\mathrm{F}$ tend to resemble $\mathrm{F}^{\prime}$ and $\mathrm{H}$. Most run at high altitude $(>10-12 \mathrm{~km})$ just south of the STJ, but none of them intersects cumulonimbus venting, which might point to a biomass burning or lightning source for ozone. Some originate from the region west of North Africa but are not close to either lightning or potential venting of biomass burning.

[48] An exception is the trajectory for G, 11 March, which flows from a region of convective activity, with the cloud base region positioned to receive Asian pollution influence by convergence. Thus $\mathrm{O}_{3}$ soundings on consecutive days can have different sources, with a stratospheric influence giving way to an episode of lofted pollution. The implication is that the TTO maps (Figures 4 and 5) may also show high integrated tropospheric $\mathrm{O}_{3}$ because of differing processes.

\section{Differing Winds and Ozone Over Atlantic and Indian Oceans}

[49] Ozone observed over the Indian Ocean showed very different variations from those observed over similar latitudes in the tropical Atlantic [Chatfield et al., 2004, and references therein]. Figure 13 helps explain this. The structure of wind systems is strongly defined over the $\sim 0$ longitude region near West Africa, as indicated by the zonal wind analysis of this figure. High mean zonal 


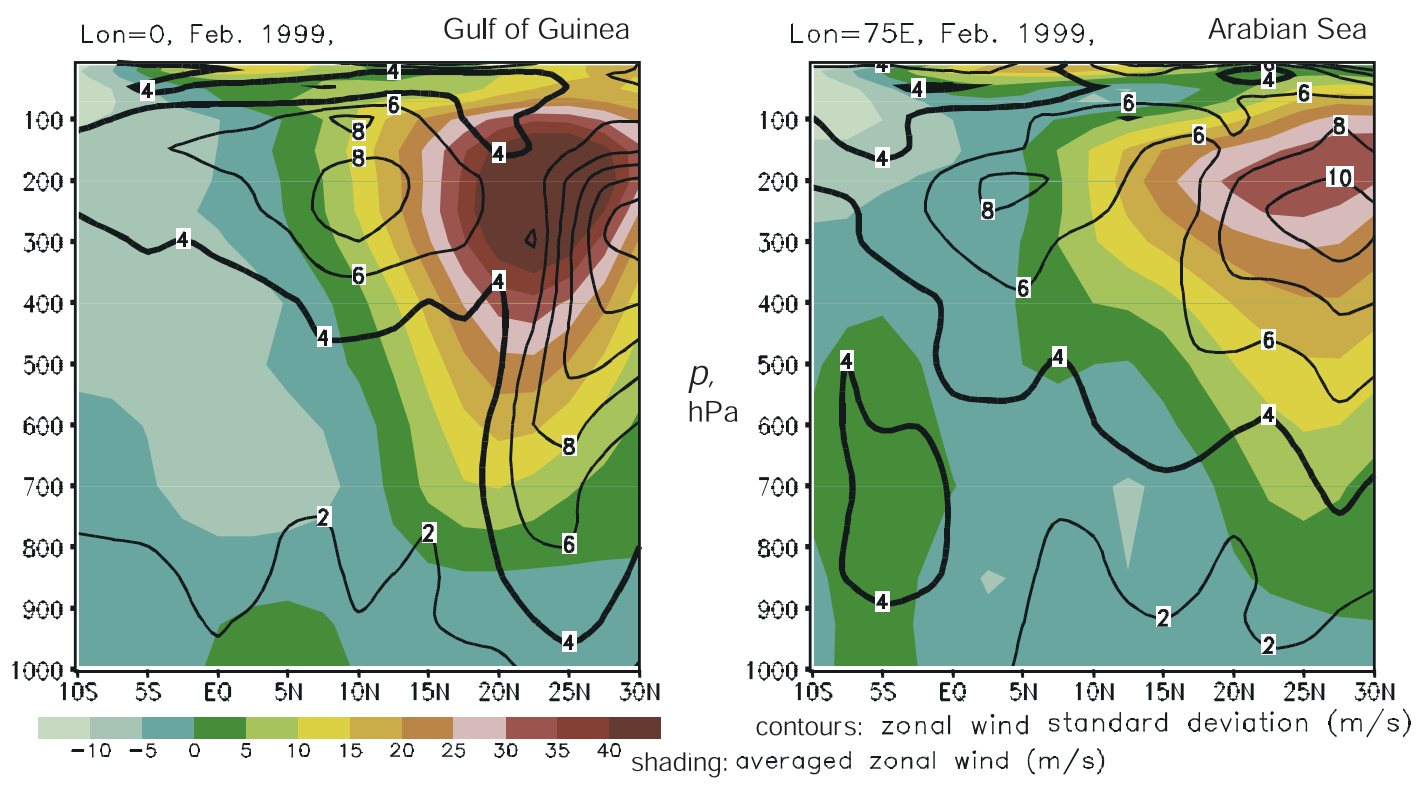

Figure 13. Statistics of NCEP westerly wind along regions running through Arabian Sea as compared to Gulf of Guinea. Colored regions show mean zonal westerly wind at 0 and $75^{\circ} \mathrm{E}$, while black contours show standard deviation of the wind. Note the concentration of the zonal wind near West Africa and its broadening to the south near India. The variability of the wind is even more pronounced. Examine particularly the $4 \mathrm{~m} \mathrm{~s}^{-1}$ contour.

westerlies prevail much further south in the upper troposphere over the Indian Ocean (longitude $75^{\circ} \mathrm{E}$ ), reaching to $\sim 7^{\circ} \mathrm{N}$ rather than $15^{\circ} \mathrm{N}$. The variability of the zonal wind is even more extended to the south over the Indian Ocean, as the $4 \mathrm{~m} \mathrm{~s}^{-1}$ contour of Figure 13 shows. This is entirely consistent with the way that trajectories from the north recurve and allow subsidence of stratospherically influenced air (or perhaps air related to extremely distant cumulonimbus outflow). It is also quite consistent with rapid alteration of high $\mathrm{O}_{3}$ features resulting from very different processes.

\section{Summary and Conclusions}

[50] A sequence of daily satellite tropospheric $\mathrm{O}_{3}$ maps in combination with two ozonesonde series provides a very informative picture of tropical $\mathrm{O}_{3}$ over the Indian Ocean during the INDOEX (early 1999) period. The views complement and extend prior analyses [de Laat, 2002; Zachariasse et al., 2000, 2001; Rasch et al., 2001; Chatfield et al., 2004] describing sources of $\mathrm{O}_{3}$ and other smog species over the region. This work focuses on transport patterns affecting $\mathrm{O}_{3}$ variability, often revealed through satellite observations as approximately east-west streaks near the eastern end of the "high $\mathrm{O}_{3}$ tropics" [Fishman and Larsen, 1987; Thompson et al., 2003; Wang et al., 2006]. Previous work [Chatfield et al., 2004] showed frequently interacting high $\mathrm{O}_{3}$ features from Indochina to Brazil. Here it is shown that variability and sources of Indian Ocean ozone differ markedly from the Atlantic patterns described in the works of Thompson et al. [2000] and Chatfield et al. [2004].

[51] Two principal processes appear to be responsible: (1) stratospheric air moving into the tropics and (2) lofting of local pollution associated with the large population centers of Asia. Industrial and small-scale biofuel burning cannot be distinguished. Ancillary meteorological and satellite maps suggest mechanisms leading to $\mathrm{O}_{3}$ buildups responsible for east-west bands. The analysis is further enhanced by analysis of $\mathrm{O}_{3}$ and humidity layers in the sondes.

[52] Lower tropospheric $\mathrm{O}_{3}$ over the Arabian Sea is strongly controlled by convective activity just south of Sri Lanka. Figures 1 and 2 suggest that ozone buildups in the region extend from 900 to $450 \mathrm{hPa}$ or so. At times, wellplaced convection enhances low-level convergence of air from the Indian subcontinent to the Indian Ocean, enhancing the pollution flux. The largest concentrations of such lower tropospheric $\mathrm{O}_{3}$ over the Arabian Sea are associated with transport from high emission regions in the central and northern subcontinent. Layers of lower tropospheric ozone appear to vary in accord with the Madden-Julian oscillation previously described [Rasch et al., 2001].

[53] Sources of middle-to-upper tropospheric $\mathrm{O}_{3}$ include Asian pollution, and stratospheric $\mathrm{O}_{3}$, with the larger contribution (to $40 \mathrm{ppbv}$ ) from the latter source. This descending $\mathrm{O}_{3}$ did not remain in the tropics and then moved westward, for example, affecting Africa or the Atlantic, for the period of study. Stratospherically influenced (or very long distance) vented ozone alternated with Indian subcontinent pollution for regions north of $\sim 10^{\circ} \mathrm{N}$. Since such $\mathrm{O}_{3}$ and water vapor are strongly negatively correlated, the radiative effect is presumed to maximize exactly when the radiative effect of water vapor is a minimum.

[54] An important conclusion from our study is that the requirements for improved understanding of tropical $\mathrm{O}_{3}$ have progressed to the point that daily, not seasonal or interannual, data are needed to differentiate and quantify different mechanisms and to evaluate terms in the ozone budget. As the present satellite data show, much progress 
has been made in developing integrated space-based observations, but further development is needed for optimized sampling, accurate simulations, and forecasting.

[55] Approaches must recognize the challenges of tracking ozone as a pollutant and as a species that complements upper tropospheric water vapor in roles of radiative forcing and climate dynamics. As strategies are perfected, we can anticipate progress to accurate short-term forecasts as well as prediction of ozone-climate interactions.

\section{Appendix A}

[56] Deducing air parcel origin from moisture structure. The thermal and humidity structure sampled along with ozone provides useful information about $\mathrm{O}_{3}$ origins that are used in Figures 1, 2, and 12. A useful analysis of composition based on soundings is as follows. We can associate the humidity, temperature, and $\mathrm{O}_{3}$ of any point on the sounding with a hypothetical air parcel, and consider the motions of the parcel and how ozone and water mixing ratio as well as energy are affected from probable origins. (It is acknowledged from the outset that mixing can occur, in relatively infrequent but vigorous bursts.) Since there is limited information, the approach is to consider origins involving one parcel or, if possible, two parcels.

[57] The simplest approach is to consider the water vapor and $\mathrm{O}_{3}$ to be essentially conserved from a defining event, namely, the time when the parcel last evaporated from a cloud when it mixed with the environment or descended. In each case, the relative humidity at the parcel-defining evaporation point was $100 \%$. Air originating from the stratosphere had its water mixing ratio set there by slightly more complex processes. Pure stratospheric air would have only $\sim 6 \mathrm{ppm}$ of water. Ozone is considered to be conserved in the middle and upper free troposphere for many weeks, unless evaporation is accompanied by the addition of lightning-produced nitrogen oxides or lofted organics.

[58] Water vapor mixing ratio should be similarly conserved along the trip from cloud detrainment point. Whereas relative humidity is often used to indicate descent and air mass origins, it changes (decreases) because of the major effect of increased temperatures at lower altitudes, and because of a lesser effect: As the air descends, it compresses at higher surrounding pressure, and there is more water vapor pressure, a countervailing increase in relative humidity. Since the vertical temperature gradient runs from $\sim 6$ to $10 \mathrm{~K} / \mathrm{km}$ in most of the troposphere, the former effect, the effect of saturation vapor pressure, is dramatic. Mixing ratios change by factors of 10 for relatively modest displacements (Figure 12). Restating this concept, under the assumption of nonmixing, the mixing ratio of a parcel tends to locate precisely its last evaporation (detrainment) altitude, its "last saturated height" (abbreviated saturated height), because temperature varies so rapidly with height.

[59] For analysis, water vapor tracer is plotted using a saturated height, which indicates origins and on an easily grasped linear scale. Alternatively, one can plot the difference between the saturated height and the actual height of humidity observation. As Figures 1 and 2 indicate, each alternative reflects certain aspects of the ozone distribution and has merits.
[60] More careful analysis of the humidity structure of the atmosphere suggests that water vapor mixing ratio is not completely conserved over long periods of time. The major effect appears to be the evaporation of falling precipitation, typically ice crystals [Folkins and Martin, 2005, and references therein]. Second, when two parcels originating from different altitudes (detrainment temperatures) mix, an analysis of the resulting mixed parcel appears to come from a position nearer the lower altitude. (Consider that the temperature is nearly a linear function of altitude, and that the saturation vapor pressure is a steeply increasing exponential function of temperature.) Both of these considerations suggest that the analysis may point to origins somewhat lower in the atmosphere than true origins. Our experience with analysis of the troposphere above the first $2-3 \mathrm{~km}$ is that both mixing events and moistening events are intermittent, so that uniform time-dependent "corrections" are not very useful.

[61] The temperature structure of the tropical ozone soundings may give additional information. Thermal energy (potential temperature) of a parcel can change relatively rapidly in the troposphere, responding to radiative and dynamical processes. Nevertheless, when a parcel in a layer responds to a subsidence process, there tends to be a slight but coherent behavior, the production of a stable layer.

[62] In each of these analyses, a given sounding is taken to characterize the general features of troposphere at the detrainment point. This is an imperfect assumption but probably acceptable to first order, considering the large disparity between vertical and horizontal temperature gradients in the troposphere.

[63] Acknowledgments. We would like to acknowledge the aid of Philip Rasch for assimilated aerosol and the SHADOZ (http://croc.gsfc. nasa.gov/shadoz) team including those at Kaashidhoo, and also to the very helpful suggestions made on early drafts by Katja Drdla (NASA, Ames) and Ian Folkins (Dalhousie U.). We are grateful to the support from NASA's programs in Atmospheric Chemistry Modeling and Analysis and Radiation Science, RTOPs 622-55-54-10 and 622-61-14-10.

\section{References}

Baray, J. L., G. Ancellet, F. G. Taupin, M. Bessafi, S. Baldy, and P. Keckhut (1998), Subtropical tropopause break as a possible stratospheric source of ozone in the tropical troposphere, J. Atmos. Sol. Terr. Phys., 60, 27-36. Chatfield, R. B., and P. J. Crutzen (1984), Sulfur dioxide in remote oceanic air: Cloud transport of reactive precursors, J. Geophys. Res., 89, 71117132 .

Chatfield, R. B., and A. C. Delany (1990), Convection links biomass burning to increased tropical ozone: However, models will tend to overpredict $\mathrm{O}_{3}$, J. Geophys. Res., 95, 18,473-18,488.

Chatfield, R. B., H. Guan, A. M. Thompson, and J. C. Witte (2004), Convective lofting links Indian Ocean air pollution to paradoxical South Atlantic ozone maxima, Geophys. Res. Lett., 31, L06106, doi:10.1029/ 2003 GL018866.

de Laat, A. T. J. (2002), On the origin of tropospheric $\mathrm{O}_{3}$ over the Indian Ocean during the winter monsoon: African biomass burning vs. stratosphere-troposphere exchange, J. Atmos. Chem. Phys., 2, 325-341.

Dickerson, R. R. (1984), Measurements of reactive nitrogen compounds in the free troposphere, Atmos. Environ., 18, 2585-2593.

Edwards, D. P., et al. (2003), Tropospheric ozone over the tropical Atlantic: A satellite perspective, J. Geophys. Res., 108(D8), 4237, doi:10.1029/ 2002JD002927.

Fishman, J., and J. C. Larsen (1987), The distribution of total ozone and stratospheric ozone in the tropics: Implications for the distribution of tropospheric ozone, J. Geophys. Res., 92, 6627-6634.

Fishman, J., C. E. Watson, J. C. Larsen, and J. A. Logan (1990), Distribution of tropospheric ozone determined from satellite data, J. Geophys. Res., 95, 3599-3617.

Fishman, J., A. E. Wozniak, and J. K. Creilson (2003), Global tropospheric ozone from satellite measurements using the empirically corrected tropo- 
spheric ozone residual technique: Identification of the regional aspects of air pollution, J. Atmos. Chem. Phys, 3, 893-907.

Folkins, I., and R. V. Martin (2005), The vertical structure of tropical convection and its impact on the budgets of water vapor and ozone, J. Atmos. Sci., 62, 1560-1573.

Forêt, G., C. Flamant, S. Cautenet, J. Pelon, M. Taghavi, and P. Chazette (2005), The structure of the haze plume over the Indian Ocean during INDOEX: Tracer simulations and LIDAR observations, Atmos. Chem. Phys. Disc., 5, 3312-3629.

Giglio, L., J. D. Kendall, and C. J. Tucker (2000), Remote sensing of fires with the TRMM VIRS, Int. J. Remote Sens., 21, 203-207.

Hudson, R. D., and A. M. Thompson (1998), Tropical tropospheric ozone (TTO) maps from TOMS by a modified-residual method, J. Geophys. Res., 103, 22,129-22,145.

Hudson, R. D., J. Kim, and A. M. Thompson (1995), On the derivation of tropospheric column ozone from radiances measured by the total ozone mapping spectrometer, J. Geophys. Res., 100, 11,137-11,145.

Jenkins, G., J.-H. Ryu, A. M. Thompson, and J. C. Witte (2003), Linking horizontal and vertical transport of biomass fire emissions to the tropical Atlantic Ozone Paradox during the Northern Hemisphere winter season: 1999, J. Geophys Res., 108, 4745, doi:10.129/2002JD003297.

Jenkins, G. M., and D. G. Watts (1968), Spectral Analysis and its Applications, Holden-Day, Boca Raton, Fla.

Kim, J. H., M. J. Newchurch, and K. Han (2001), Distribution of tropical ozone determined by scale-angle method applied to TOMS measurements, J. Atmos. Sci., 58, 2699-2708.

Kim, J. H., S. Na, M. J. Newchurch, and R. V. Martin (2005), Tropical tropospheric ozone morphology and seasonality seen in satellite and in situ measurements and model calculations, J. Geophys. Res., 110, D02303, doi:10.1029/2003JD004332.

Komhyr, W. D. (1986), Operations Handbook: Ozone measurements to $40 \mathrm{~km}$ altitude with model 4A-ECC-ozone sondes, NOAA Tech. Memo. ERLARL-149.

Komhyr, W. D., R. A. Barnes, G. B. Brothers, J. A. Lathrop, and D. P. Opperman (1995), Electrochemical concentration cell ozonesonde performance during STOIC 1989, J. Geophys. Res., 100, 9231-9244.

Krishnamurti, T. N., et al. (1996), Passive tracer transport relevant to the TRACE-A experiment, J. Geophys. Res., 101(D19), 23,889-23,907.

Krishnamurti, T. N., C. E. Levy, and H. L. Pan (1975), On simultaneous surges in the trades, J. Atmos. Sci., 32, 2367-2370.

Krishnamurti, T. N., B. Jha, J. M. Prospero, A. Yayaraman, and V. Ramanathan (1998), Aerosol and pollutant transport over the tropical Indian Ocean during the 1996 northeast monsoon and the impact on radiative forcing, Tellus, 50B(5), 521-542.

Lal, S., M. Naja, and A. Jayaraman (1998), Ozone in the marine boundary layer over the tropical Indian Ocean, J. Geophys. Res., 103, 18,907$18,917$.

Lawrence, M. G., et al. (2003), Global chemical weather forecasts for field campaign planning: predictions and observations of large-scale features during MINOS, CONTRACE, and INDOEX, Atmos. Chem. Phys., 3, $267-289$.

Lelieveld, J., et al. (2001), The Indian Ocean experiment: Widespread air pollution from South and Southeast Asia, Science, 291, 1031-1036.

Logan, J. A. (1999), An analysis of ozonesonde data for the troposphere: recommendations for testing 3-D models and development of a gridded climatology for tropospheric ozone, J. Geophys. Res., 104, 16,11516,149 .

Logan, J. A., and V. W. J. H. Kirchhoff (1986), Seasonal variations of tropospheric ozone at Natal, Brazil, J. Geophys. Res., 91, 7875-7882.

Liu, X., K. Chance, C. E. Sioris, R. J. D. Spurr, T. P. Kurosu, R. V. Martin, M. J. Newchurch, and P. K. Bhartia (2005), Ozone profile and tropospheric ozone retrievals from Global Ozone Monitoring Experiment: Algorithm description and validation, J. Geophys. Res., D20307, doi:10.1029/2005JD006240.

Mandal, T. (2002), On the origin of tropospheric $\mathrm{O}_{3}$ over the Indian Ocean during the winter monsoon: African biomass burning vs. stratospheretroposphere exchange, Atmos. Chem. Phys. Disc., 2, S358-S361.

Martin, R. V., et al. (2002), Interpretation of TOMS observations of tropical tropospheric ozone with a global model and in situ observations, J. Geophys. Res., 107(D18), 4351, doi:10.1029/2001JD001480.

Moxim, W. J., and H. Levy II (2000), A model analysis of the tropica South Atlantic Ocean tropospheric ozone maximum: The interaction of transport and chemistry, J. Geophys. Res., 105, 17,393-17,415.

Oltmans, S. J., et al. (2001), Ozone in the Pacific tropical troposphere from ozonesonde observations, J. Geophys. Res., 106, 32,503-32,526.

Peshin, S. K., T. K. Mandal, H. G. J. Smit, S. K. Srivastav, and A. P. Mitra (2001), Observations of vertical distribution of tropospheric ozone over
Indian Ocean and its comparison with continental profiles during INDOEX-FFP-1998 and IFP-1999, Curr. Sci. (Suppl.), 80, 197-208.

Phadnis, M. J., H. Levy II, and W. J. Moxim (2002), On the evolution from South and Southeast Asia during the winter-spring monsoon, J. Geophys. Res., 107(D24), 4790, doi:10.1029/2002JD002190.

Pickering, K. E., A. M. Thompson, J. R. Scala, W.-K. Tao, R. R. Dickerson, and J. Simpson (1992), Free tropospheric ozone production following entrainment of urban plumes into deep convection, J. Geophys. Res., 97, 17,985-18,000.

Pickering, K. E., et al. (2001), Trace gas transport and scavenging in PEMTropics-B SPCZ convection, J. Geophys. Res., 106, 32,591-32,608.

Piotrowicz, S. R., D. A. Boran, and C. J. Fischer (1986), Ozone in the boundary layer of the equatorial Pacific Ocean, J. Geophys. Res., 91, $13,113-13,119$

Rasch, P. J., W. D. Collins, and B. E. Eaton (2001), Understanding the Indian Ocean Experiment (INDOEX) aerosol distributions with an aerosol assimilation, J. Geophys. Res., 106, 7337-7355.

Raman, S., D. dutta, S. Niyogi, M. Simpson, and J. Pelon (2002), Dynamics of the elevated land plume over the Arabian Sea and the northern Indian Ocean during northeasterly monsoons and during the Indian Ocean experiment (INDOEX), Geophys. Res. Lett., 29(16), 1817, doi:10.1029/ 2001GL014193.

Reiner, T., D. Sprung, C. Jost, R. Gabriel, O. L. Mayol-Bracero, M. O. Andreae, T. L. Campos, and R. E. Shetter (2001), Chemical characterization of pollution layers over the tropical Indian Ocean: Signatures of emissions from biomass and fossil fuel burning, J. Geophys. Res., 106, 28,497-28,510.

Routhier, F., K. Dennett, D. D. Davis, A. Wartburg, P. Haagenson, and A. C. Delany (1980), Free tropospheric and boundary-layer airborne measurements of ozone over the latitude range of $58 \mathrm{deg} \mathrm{S}$ to $70 \mathrm{deg} \mathrm{N}$, J. Geophys. Res., 85, 7307-7321.

Schoeberl, M. A., and P. A. Newman (1995), A multiple level trajectory analysis of vortex filaments, J. Geophys. Res., 100, 25,801-25,815.

Smit, H. G. J., W. Sträter, D. Kley, and M. H. Profitt (1994), The evaluation of ECC-ozonesondes under quasi-flight conditions in the environmenta simulation chamber at Jülich, in Proceedings of Eurotrac Symposium 1994, edited by P. M. Borell et al., Elsevier, New York.

Thompson, A. M., and R. D. Hudson (1999), Tropical tropospheric ozone (TTO) maps from Nimbus 7 and Earth Probe TOMS by the modifiedresidual method: Evaluation with sondes, ENSO signals, and trends from Atlantic regional time series, J. Geophys. Res., 104, 26,961-26,975.

Thompson, A. M., K. E. Pickering, D. P. McNamara, M. R. Schoeberl, R. D. Hudson, J. H. Kim, E. V. Browell, V. W. J. H. Kirchhoff, and D. Nganga (1996), Where did tropospheric ozone over southern Africa and the tropical Atlantic come from in October 1992? Insights from TOMS, GTE/TRACE-A and SAFARI-92, J. Geophys. Res., 101, $24,251-24,278$

Thompson, A. M., B. G. Doddridge, J. C. Witte, R. D. Hudson, W. T. Luke, J. E. Johnson, B. J. Johnson, S. J. Oltmans, and R. Weller (2000), A tropical Atlantic ozone paradox: Shipboard and satellite views of a tropospheric ozone maximum and wave one in January-February 1999 , Geophys. Res. Lett., 27(20), 3317-3320.

Thompson, A. M., et al. (2003), Southern hemisphere additional ozonesondes (SHADOZ) 1998-2000 tropical ozone climatology 2. Tropospheric variability and the ozone wave-one, J. Geophys. Res., 108(D2), 8241, doi:10.1029/2002JD002241.

Vingarzan, R. (2004), A review of surface ozone background levels and trends, Atmos. Environ., 38, 3431-3442.

Wang, P.-H., J. Fishman, V. L. Harvey, and M. H. Hitchman (2006), Southern tropical upper tropospheric zonal ozone wave-1 from SAGE II observations (1985-2002), J. Geophys. Res., 111, D08305, doi:10.1029/2005JD006221.

Zachariasse, M., et al. (2000), Influence of stratosphere-troposphere exchange on tropospheric ozone over the tropical Indian Ocean during the winter monsoon, J. Geophys. Res., 105, 15,403-15,416.

Zachariasse, M., et al. (2001), Cross-tropopause and interhemispheric transports into the tropical free troposphere over the Indian Ocean, J. Geophys. Res., 106(D22), 28,441-28,452.

R. B. Chatfield, Earth Science Division, NASA Ames Research Center, Mail Stop 245-5, Moffett Field, CA 94035-1000, USA. (chatfield@ clio.arc.nasa.gov)

H. Guan, Bay Area Environmental Research Institute, Sonoma, CA, USA. (guan@clio.arc.nasa.gov)

H. G. J. Smit, Forschungszentrum Jülich, Jülich, Germany.

A. M. Thompson, Department of Meteorology, Pennsylvania State University, University Park, PA, USA 